\title{
Article
}

\section{Rare earth element geochemistry of altered pyroclastic rocks in the Hashtjin area of north-west Iran}

\author{
Tohid Nouri ${ }^{1}$, Parvin Najafzadeh Tehrani ${ }^{2 *}$, Rahim Masoumi ${ }^{2}$ and George E. Christidis ${ }^{3}$ \\ ${ }^{1}$ Department of Civil Engineering, University of Mohaghegh Ardabili, Ardabil, Iran, ${ }^{2}$ Department of Earth Sciences, Faculty of Natural Sciences, University of Tabriz, \\ Iran and ${ }^{3}$ Technical University of Crete, School of Mineral Resources Engineering, 73100 Chania, Greece
}

\begin{abstract}
This study evaluates the rare earth element $(R E E)$ geochemistry in altered trachyandesitic ignimbrites, tuff and lava flows in the Hashtjin area by assessing chondrite-normalized REE patterns and Y/Ho geochemical ratios. Modifications in the REE patterns took place along altered fault zones that were affected by hypogene and supergene alterations. The precursor volcanic and pyroclastic rocks contain phenocrysts of plagioclase accompanied by augite, zircon, apatite and pyrite. Based on X-ray diffraction analysis, the main mineral assemblages of the altered units consist of kaolinite as the main clay mineral, $\mathrm{SiO}_{2}$ polymorphs (quartz and cristobalite) and anatase as a minor constituent. The chondrite-normalized REE patterns of argillic samples reveal fractionation of light REEs (LREEs) compared to heavy REEs (HREEs), together with a marked Eu anomaly and a weak W-type tetrad effect related to the weak non-charge radius control (CHARAC) behaviour of REEs and slightly higher $\mathrm{Y} / \mathrm{Ho}$ and $\mathrm{Zr} / \mathrm{Hf}$ ratios. The relationship between the $\mathrm{Y} / \mathrm{Ho}$ and $\mathrm{Zr} / \mathrm{Hf}$ ratios and recognizable $\mathrm{T}_{3}$ and $\mathrm{T}_{4}$ effects (tetrad effect) suggests that an increasing degree of water-rock interaction occurred during hypogene alteration processes by acidic hydrothermal fluids that were overprinted by supergene alteration. Water-rock interaction and adsorption by Mn-oxides and clay minerals are considered to have played important roles in determining the close to non-CHARAC behaviour of REEs during the argillic alteration of the pyroclastic rocks in the Hashtjin area.
\end{abstract}

Keywords: argillic alteration, Hashtjin, ignimbrite, kaolinization, lanthanide tetrad effect, pyroclastic rocks, REEs

(Received 11 August 2019; revised 29 June 2020; Accepted Manuscript online: 15 July 2020; Associate Editor: Lawrence Warr)

Rare earth elements (REEs) provide useful petrological information for determining the nature of geological events such as the origin of rocks and their contamination-differentiation processes (Hanson, 1989; Bau \& Knittel, 1993). A large amount of REE data has been obtained, representing the differentiation between various minerals and melts (Rollinson, 1993), as well as changes occurring in hydrothermal systems at temperatures $<350^{\circ} \mathrm{C}$ (Hermann et al., 1974; Michard \& Albarede, 1986; Wood, 1990; Jochum \& Verma, 1996), under metamorphic conditions (Konrad-Schmolke et al., 2011) and during weathering (Pérez-López et al., 2010).

REEs are also useful for assessing geochemical processes during the evolution of sediments in various environments (Chen \& Zhao, 1997; Censi et al., 2007; Karadağ et al., 2009; Hannigan et al., 2010; Mongelli et al., 2016; Abedini et al., 2018). The distribution and differentiation of REEs have also been well studied in seawaters, marine sediments and weathering environments (Abedini \& Calagari, 2013; Mongelli et al., 2014; Buccione et al., 2016; Liu et al., 2016; Long et al., 2017; Torr et al., 2017; Chen et al., 2018). In these cases, the distribution patterns of REEs are generally controlled by weathering of terrestrial material, hydrothermal activities, scavenging, oxygen fugacity, proximity to source lithologies, deposition due

${ }^{\star}$ E-mail: parvin_tehranii@yahoo.com

Cite this article: Nouri T, Tehrani PN, Masoumi R, Christidis GE (2020). Rare earth element geochemistry of altered pyroclastic rocks in the Hashtjin area of north-west Iran. Clay Minerals 55, 150-165. https://doi.org/10.1180/clm.2020.21 to biogenic conditions, diagenesis (Murphy \& Dymond, 1984; Liu et al., 1988; Murray et al., 1991), changes in fluid $\mathrm{pH}$ and precipitation reactions due to the presence of organic and inorganic ligands and complexes (Buccione et al., 2016; Liu et al., 2016; Long et al., 2017; Torr et al., 2017; Chen et al., 2018).

The main aim of this study was to evaluate the behaviour of REEs (including $\mathrm{Y}$ ) during water-rock interaction in altered rocks and their volcanic precursors in the Hashtjin area, northwest Iran, and to investigate the origin of tetrad effects and nonchondritic $\mathrm{Y} / \mathrm{Ho}$ ratios in these samples. The study area includes the western part of the Alborz Tertiary magmatic belt and Pliocene volcanic activity, which was associated with tectonic activity and the formation of numerous faults (Eftekhar Nejad, 1980). The main lithological units of the area consist of volcanic rocks and Quaternary alluvial sediments that have undergone silicic and argillic hydrothermal alterations. These alterations are associated with vein, veinlet and disseminated $\mathrm{Cu}-, \mathrm{Pb}-$, $\mathrm{Zn}$-sulfide deposits and magnetite, goethite and hematite mineralizations (Hajalilou, 1999). They include extensive argillic alteration and the accumulation of $\mathrm{SiO}_{2}$ deposits in the form of cryptocrystalline quartz in the Tarom-Hashtjin zone. Previous studies have highlighted the role of both the hydrothermal processes and supergene alteration formation of these sequences in the circulation of acid sulfate solutions (Masoumi, 2010; Abedini et al., 2011; Nouri \& Mohammady Oskouei, 2016; Nouri \& Masoumi, 2020). 


\section{The tetrad effect in REE patterns and non-chondritic $\mathrm{Y} / \mathrm{Ho}$ ratios}

Normalized REE distribution diagrams produce smooth curves that remove variation due to lanthanide contraction, the OddoHarkins rule (Cantrell \& Byrne, 1987) and charge radius control (CHARAC) behaviour (Lottermoser, 1992; Bau, 1996). Any remaining irregularities in normalized distribution patterns, such as the lanthanide tetrad effect, relate to the non-CHARAC behaviour of REEs and have been reported from various depositional environments (Censi et al., 2007; Feng et al., 2011; Nardi et al., 2012; Abedini et al., 2018). Such effects can be detected using index parameters, namely $\mathrm{Y} / \mathrm{Ho}, \mathrm{Zr} / \mathrm{Hf}, \mathrm{Ce} / \mathrm{Ce}^{\star}$ and $\mathrm{Eu} / \mathrm{Eu}^{\star}$ ratios (Kawabe, 1995).

The study of REEs (lanthanides) reveals the different reactive behaviours of these elements in various geological environments, which result from differences in the ionic radius (i.e. increase in the contraction of $5 \mathrm{~s}$ and $5 \mathrm{p}$ shells towards higher atomic numbers) and, in some cases, in the ionic valence redox state $\left(\mathrm{Ce}^{3+}\right.$ vs $\mathrm{Ce}^{4+}$ and $\mathrm{Eu}^{2+} v s \mathrm{Eu}^{3+}$ ) (Monecke et al., 2002). The tetrad effect is not related to the ionic radius and ionic charge, but it is directly controlled by electrons of the $\mathrm{f} 4$ shell across the lanthanide series (Nugent, 1970; Siekierski, 1971).

The tetrad effect was observed for the first time during experiments on liquid-liquid chemical systems in which the distribution coefficient of lanthanides in chondrite-normalized REE patterns varied according to changes in atomic number (Fidelis \& Siekierski, 1966; Peppard et al., 1969). These variations yielded zigzag patterns, which created four separate components referred to as tetrads, defined by a first tetrad $\left(\mathrm{T}_{1}\right)$ : La-Ce-Pr-Nd; a second tetrad $\left(\mathrm{T}_{2}\right)$ : $(\mathrm{Pm})-\mathrm{Sm}-\mathrm{Eu}-\mathrm{Gd}$; a third tetrad $\left(\mathrm{T}_{3}\right)$ : Gd-Tb-Dy-Ho; and a fourth tetrad $\left(\mathrm{T}_{4}\right)$ : Er-Tm-Yb-Lu. The four segments are separated by discontinuities located at the $\mathrm{Pm}-\mathrm{Nd}$, Gd and Er-Ho points, whereby Gd is a joint element between the second and third tetrads. The components of the chondrite-normalized patterns show four convex and concave segments and, in accordance with variations in the electron configuration, the REEs display either $\mathrm{M}$-shaped or $\mathrm{W}$-shaped patterns (Fig. 1) (Masuda et al., 1987).

The M-shaped tetrad effect was first recognized in the evolved granitic systems in the south of China (Masuda et al., 1987) and the $\mathrm{W}$-shaped tetrad effect was identified in constituents of the marine environment such as seawater, algae, shells and limestones (Masuda \& Ikeuchi, 1979). In the W-type tetrad, Yb and Dy appear in an ascending trend and Er defines a descending segment (Fig. 1). Tetrad effects were also identified in magmatic rocks and hydrothermal ore deposits (Masuda \& Akagi, 1989; Akagi et al., 1993, 1996; Lee et al., 1994; Kawabe, 1995; Bau, 1996; Lee et al., 2010), as well as in weathering and hydrothermal alterations (Masuda \& Akagi, 1989; Takahashi et al., 2002; Monecke et al., 2007; Abedini et al., 2018; Li et al., 2020).

The related geochemical properties of $\mathrm{Hf}-\mathrm{Zr}$ and $\mathrm{Y}-\mathrm{Ho}$ pairs result from the similar charge and radius of the ions, known as the CHARAC behaviour (Bau, 1996), as testified by close to equivalent $\mathrm{Y} / \mathrm{Ho}$ and $\mathrm{Zr} / \mathrm{Hf}$ ratios in intermediate to basic igneous rocks and chondrites. Otherwise, these elements show significant departures from the non-chondrite state and display tetrad effect patterns, such as the zigzag REE patterns documented for evolved granite systems (Irber, 1999). The Y/Ho ratio of chondrite is 28.1 (Anders \& Grevesse, 1989), and the rocks with a tetrad effect show either higher or lower non-chondrite $\mathrm{Y} / \mathrm{Ho}$ ratios (Bau, 1996). The non-chondrite behaviour in the aqueous systems

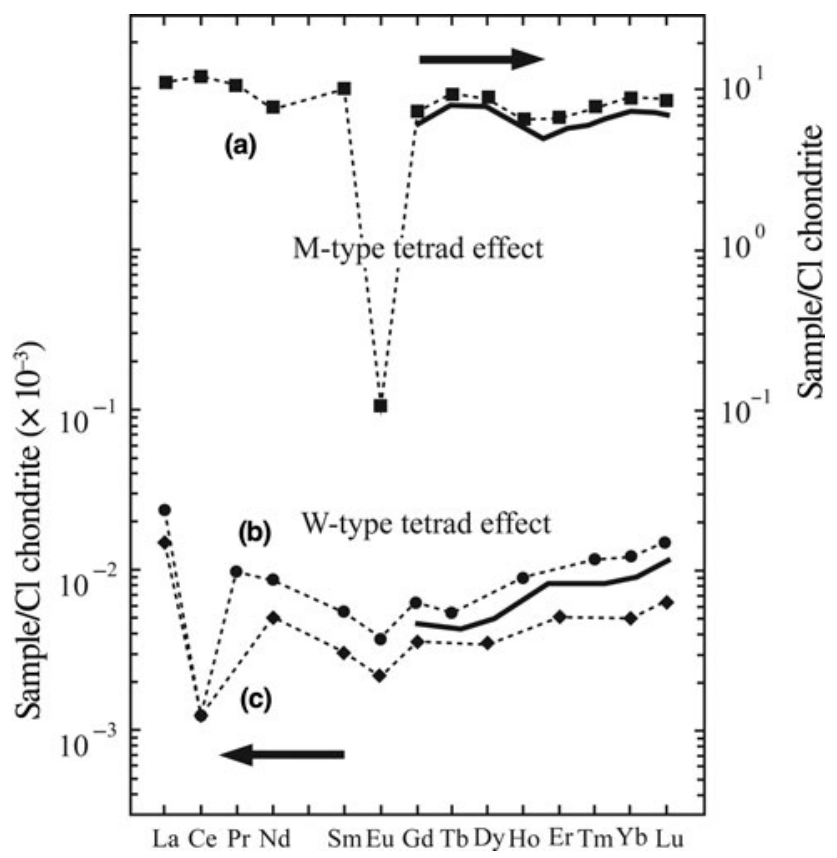

Fig. 1. Binary diagram representing $\mathrm{W}$ - and M-type tetrad effects observed in the REE patterns of seawater and evolved granite. (a) Seawater values are from De Baar et al. (1985) and (b) Piepgras \& Jacobsen (1992). Kawabe et al. (1998) show that W-type tetrad effects appear in the REE patterns of seawater. (c) REE values for the evolved granite are from Irber (1999).

may be controlled by the adsorption of Ho by Fe and Mn oxides and hydroxides (Bau et al., 1996). In addition, the fractionation of $\mathrm{Y}$ and Ho during weathering may also result in non-chondrite behaviour (Feng et al., 2011).

Although previous studies have proposed alternative models for explaining the formation of tetrad effects, the exact origin and geochemical process giving rise to this type of alteration in granites and other rocks, as well as in individual minerals, is not well understood (Veksler et al., 2005; Censi et al., 2007; Monecke et al., 2007; Inoue et al., 2009). The tetrad effect in the evolved granitic systems has been attributed to: (1) fractional crystallization of the melt (Yurimoto et al., 1990; Zhao \& Cooper, 1993; McLennan, 1994; Pan, 1997; Pan \& Breaks, 1997); (2) interaction of the melt phase and hydrothermal fluids during the crystallization of the silicate melt (Lee et al., 1994; Kawabe, 1995; Kempe \& Goldstein, 1997; Irber, 1999; Wu et al., 2004; Boulvais et al., 2007; Lee et al., 2010; Zhao et al., 2010); (3) hydrothermal alteration during water-rock interactions (Monecke et al., 2007); and (4) weathering following exhumation and erosion of granites (Masuda \& Akagi, 1989; Takahashi et al., 2002). The latter mechanism has been considered to develop M-type tetrads in granitic rocks caused by the circulation of groundwater, whereby the magnitude of alteration increases with the degree of fluidrock interaction (Masuda \& Akagi, 1989; Takahashi et al., 2002).

The fractionation of $\mathrm{Y}-\mathrm{Ho}$ and various lanthanides also occurs in aqueous systems (Kawabe et al., 1991; Feng et al., 2011), and the tetrad effect has been observed in seawater and deposited sediments. A positive $\mathrm{Y}$ anomaly is a feature associated with a $\mathrm{W}$-type tetrad effect (Kawabe et al., 1991).

Several methods have been proposed to quantify the tetrad effect (Iber, 1999; Monecke et al., 2002). In this study, we use Eq. (1) (from Monecke et al., 2002), which utilizes only the third and fourth tetrads for quantification. In the calculation, 

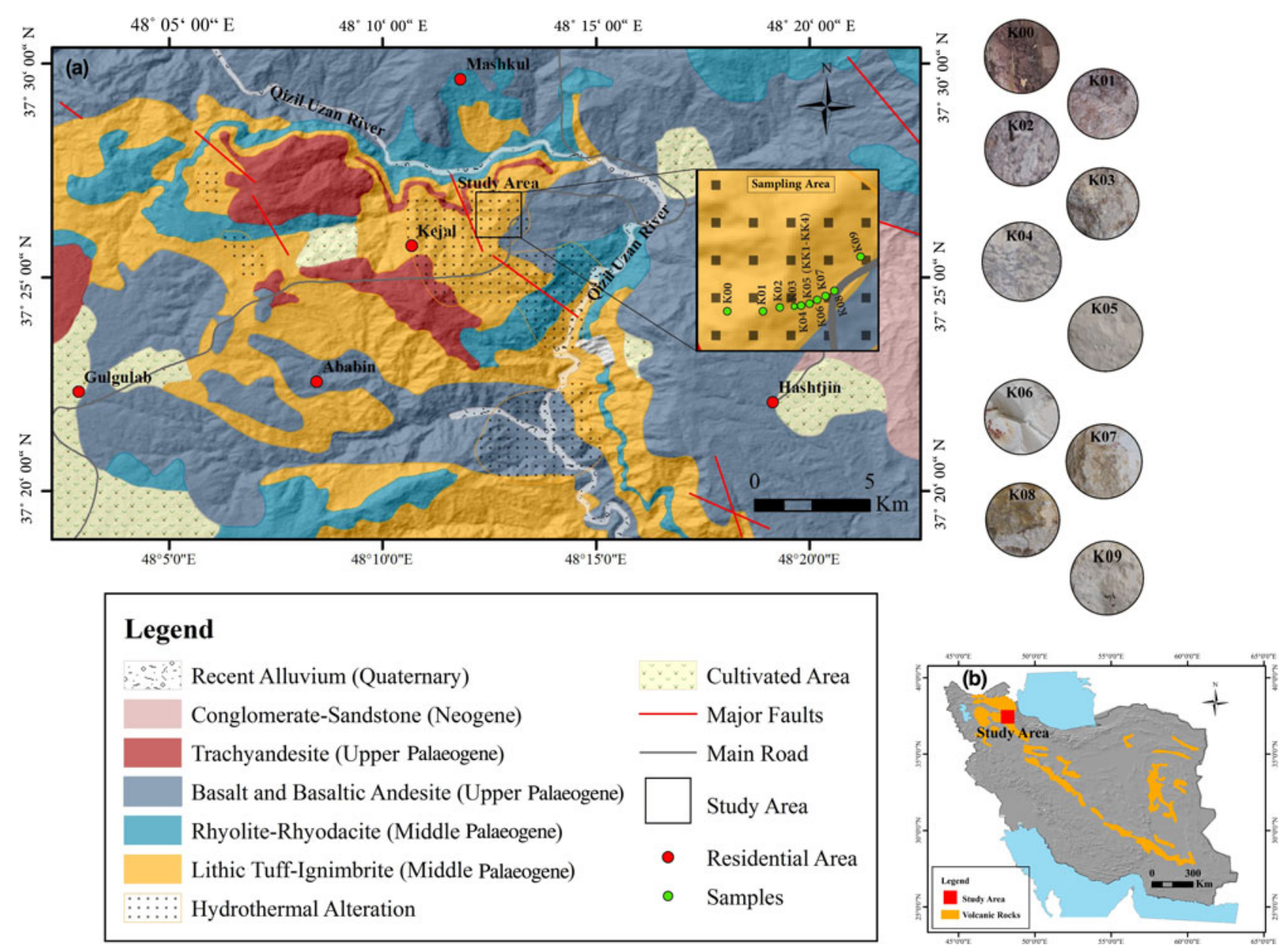

Fig. 2. (a) Location map showing the distribution of volcanic rocks throughout the Iranian plateau and the position of the study area. (b) Geological map of the Hashtjin area showing the main lithological units of the area, geological features and the selected samples of the study area for chemical analyses.

$\mathrm{T}_{1}(\mathrm{La}-\mathrm{Nd})$ is not computed if $\mathrm{Ce}$ behaves anomalously (Monecke et al., 2002; Feng et al., 2011) and $T_{2}$ (Pm-Gd) is not included due to a lack of $\mathrm{Pm}$ in natural geological systems (McLennan, 1994).

$$
T i=\sqrt{\frac{1}{2} \times\left(\left[\frac{C_{B i}}{\sqrt[3]{C_{A i^{2}} \times C_{D i}}}-1\right]^{2}+\left[\frac{C_{C i}}{\sqrt[3]{C_{D i^{2}} \times C_{A i}}}-1\right]\right)}
$$

Ti represents the type of tetrad ( $i$ denotes the group of the tetrad). When $T i=0$, this represents no tetrad effect and all of the elements of the group are located on a straight line. $T i>0$ indicates the tetrad effect in the elements of a group (Monecke et al., 2002).

\section{Geological setting}

The study area is located $20 \mathrm{~km}$ north-west of Hashtjin, northwest Iran (Fig. 2a). The Iranian plateau is considered to form part of the Tertiary magmatic zone of Alborz-Azerbaijan (Stocklin, 1977; Alavi, 1996). The oldest and youngest lithological units are Carboniferous limestones and Quaternary sediments, respectively. The red Lower Permian sandstones, as well as the Upper Jurassic and Cretaceous deposits, crop out to the northeast of Hashtjin. The Cenozoic deposits occur above an angular unconformity lying over the Palaeozoic and Mesozoic sequences.
Eocene volcanics and volcanoclastics were also emplaced discordantly across the underlying rock sequence and formed during the main stage of Cenozoic hydrothermal activity in the area. Oligocene volcanics and volcanoclastics were also deposited discordantly across the area (Fig. 2b).

Ignimbrite, trachyandesite and volcanoclastic deposits of Eocene age have been severely altered and kaolin deposits occur in some parts of the study area (Fig. 3a,b). Based on mineralogical and field evidence, the rocks have been affected by argillic alteration with clay mineral assemblages consisting of kaolinite, montmorillonite and palygorskite. The lack of pyrophyllite in this unit indicates that advanced-stage argillic alteration was not reached (Guilbert \& Park, 1986; Barnes, 1997; Hedenquist et al., 2000). The massive silicified bodies are present in argillic zones (Fig. 3b), breccia zones (Fig. 3a) and pyroclastic units. The kaolin deposit occurs in massive (Fig. 3a) and vein (Fig. 3c) forms.

In surface outcrops, iron oxides (Fig. 3a), Leisegang rings (Fig. 3d) and abundant sulfides in some kaolin samples are common geological characteristics of these mineralizations. The occurrence of kaolin veins and the intense alteration of ignimbrite, tuff and trachyandesite along fault and fractured zones (Fig. 3a,c) are suggestive of a hydrothermal origin. There is a lack of any sedimentary ore-related textures such as residual, massive and concretion textures. However, the presence of 

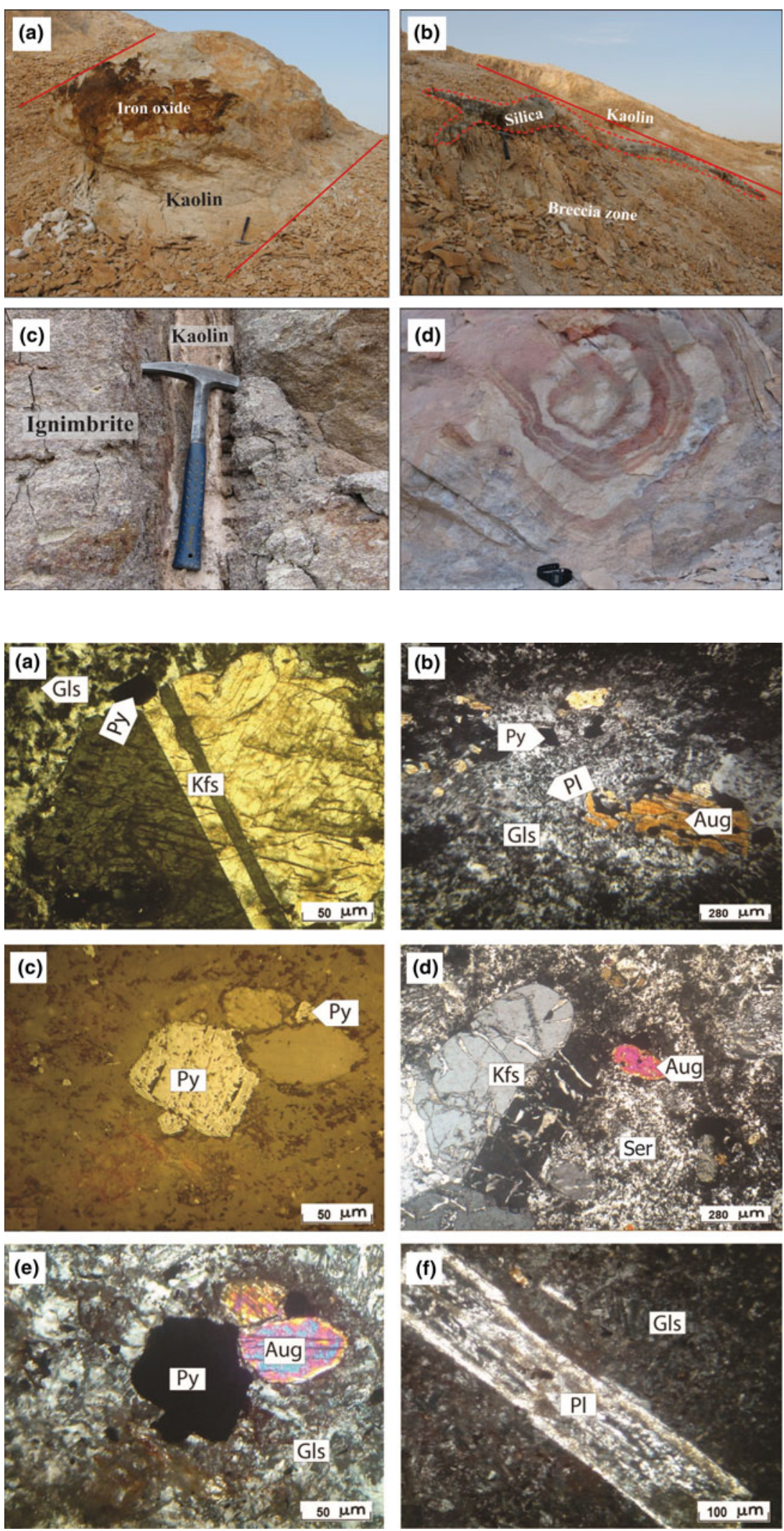

Fig. 3. Field photographs representing (a) a kaolin body with coatings of iron oxide; (b) a silica layer formed within a band of argillic alteration along a zone of hydrothermal breccia; (c) kaolin formed in fractures and fault zones; and (d) Leisegang structure in the alteration zone representing rhythmic precipitations controlled by fissures and cracks. secondary iron oxides and hydroxides reveals the occurrence of supergene processes in the area.

Due to the presence of pyrite in the volcanic parent rock and the downward flow of fluids, strongly altered units contain extensive Fe-oxide and oxy-hydroxide (goethite and hematite) precipitations.

\section{Materials and methods}

Extensive fieldwork, which included field observations, sampling and geological mapping, was carried out in the study area. Representative samples were selected for optical microscopy 

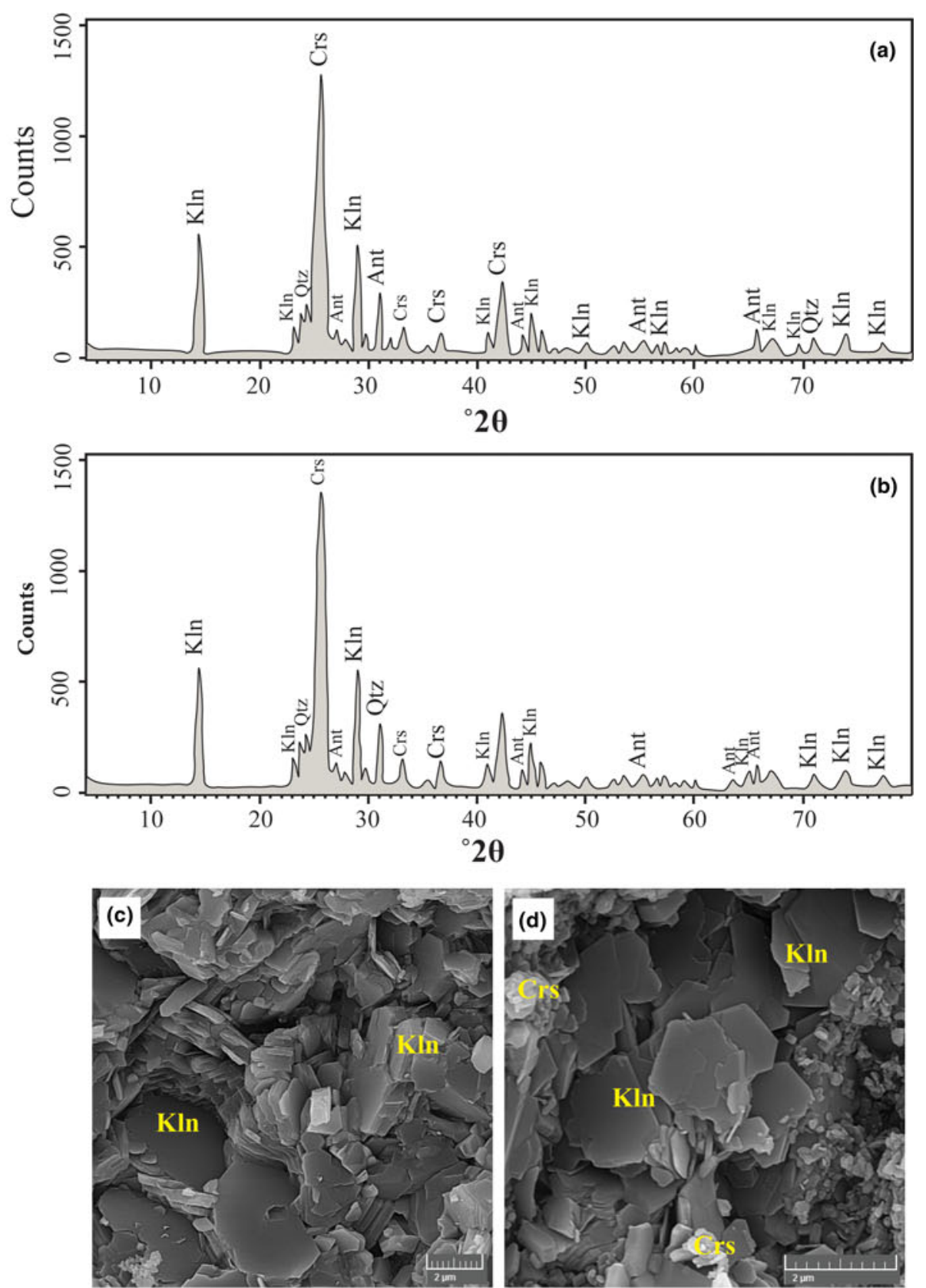

Fig. 5. $(a, b)$ XRD traces of selected samples from fully altered ignimbrites (kaolin) from the study area; kaolinite (Kln), quartz (Qtz), cristobalite (Crs) and anatase (Ant). (c-f) SEM photomicrographs representing the existing minerals: (c,d) pseudohexagonal crystals of KIn forming booklets; (e,f) KIn and Si polymorphs, probably cristobalite (Crs).
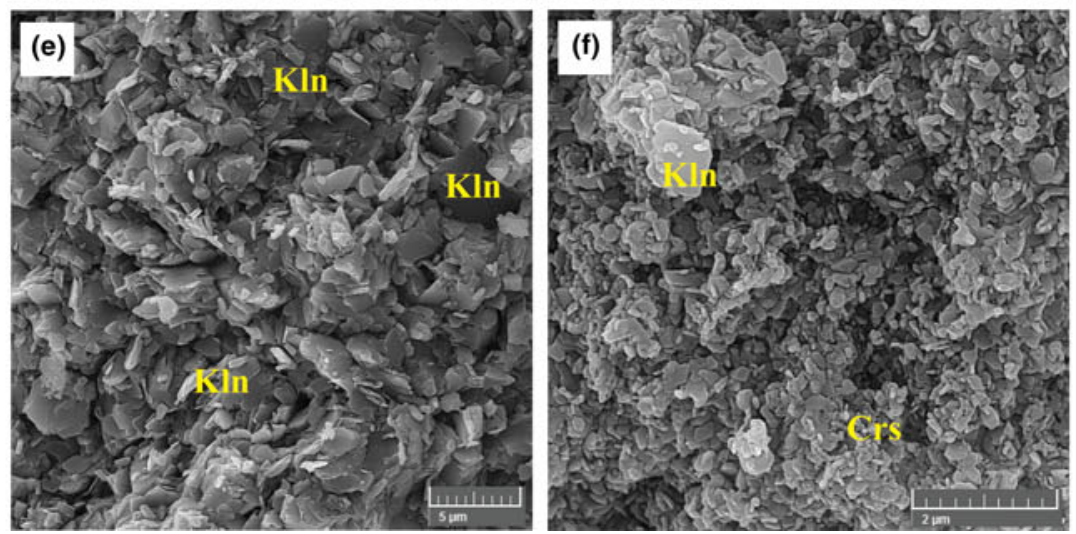


\begin{tabular}{|c|c|c|}
\hline \multirow{2}{*}{$\begin{array}{l}\text { Hydrothermal and } \\
\text { supergene alteration }\end{array}$} & \multicolumn{2}{|l|}{ Decreasing age } \\
\hline & Hypogene & Supergene \\
\hline \multicolumn{3}{|l|}{ Sericite } \\
\hline \multicolumn{3}{|l|}{ Pyrite } \\
\hline \multicolumn{3}{|l|}{ Quartz } \\
\hline \multicolumn{3}{|l|}{ Kaolinite group } \\
\hline \multicolumn{3}{|l|}{ Calcite } \\
\hline Goethite & & \\
\hline
\end{tabular}

Fig. 6. Paragenetic sequences of the ore and gangue minerals in the Hashtjin area.

Table 1. Major oxide contents (wt.\%) of the ignimbritic parent rock and the argillic samples of the north-west Hashtjin area using the ICP-MS method.

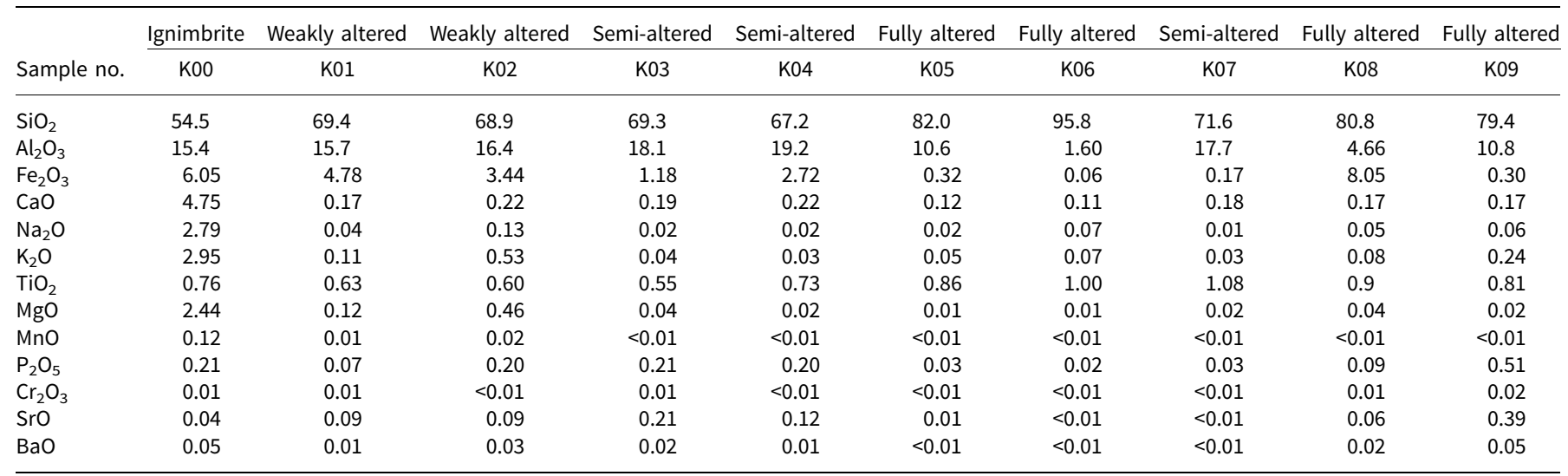

(OM), X-ray diffraction (XRD), scanning electron microscopy (SEM) and inductively coupled plasma atomic emission and mass spectrometry (ICP-AES and ICP-MS, respectively) analysis. The mineralogy of the samples for partially altered and wellkaolinized samples was determined by XRD with a Philips PW1800 diffractometer (Cu-Ko radiation, $40 \mathrm{kV}, 30 \mathrm{~mA})$ in the Kansaran Binaloud Laboratory. Representative samples were analysed in the ALS Chemex Laboratory, Canada, with ICP-AES and ICP-MS used to determine the main, minor and trace elements, as well as the REEs. Loss on ignition (LOI) values were determined from the weight changes before and after the heating of samples at $1000^{\circ} \mathrm{C}$ for $1 \mathrm{~h}$. Mineral textures were observed by SEM using a VEGA TESCAN-LMU and a FESEM MIRA3 TESCAN-XMU instrument in the Razi Metallurgical Research Center, Iran.

\section{Results and interpretations}

\section{Mineralogy}

The mineralogy of the volcanic rocks in the study area typically consist of K-feldspar phenocrysts set in a glass matrix (Fig. 4a) that were altered to sericite (Fig. 4d,f). Needle-shaped plagioclase, augite, pyrite, zircon and apatite are also present (Fig. 4b-e). Textures and elemental analyses indicate that the rocks are ignimbrites with a trachyandesitic composition (Masoumi, 2010). $\mathrm{SiO}_{2}$ polymorphs (quartz and cristobalite) and kaolinite are the main mineral phases of alteration with minor amounts of anatase as a common accessory phase (Fig. 5a,b). Kaolinite occurs as well-crystallized pseudo-hexagonal crystals often forming booklets (Fig. $5 \mathrm{c}-\mathrm{e}$ ). Spherical grains of cristobalite also occur on kaolinite crystal surfaces (Fig. 5f).

\section{Alteration}

Based on field observations, petrographic examination and XRD analyses, the volcanic rocks suffered two distinct episodes of alteration: (1) hypogene and (2) supergene (Fig. 6). The hypogene alteration may be divided into two stages: (1) early and (2) late. The early stage involved sericitic or hydrolytic alterations accompanied by the formation of pyrite \pm sericite \pm quartz assemblages disseminated within the host rocks (Fig. 4c,d,f). The late stage comprised argillic alteration accompanied by the formation of a kaolin \pm quartz assemblage occurring as veins/veinlets within the host rocks. During hydrolytic alteration, fine-grained sericite originated from the dissolution of K-feldspars in the parent rocks during the circulation of hydrothermal fluids. These acidic fluids leached $\mathrm{K}^{+}, \mathrm{Na}^{+}, \mathrm{Ca}^{2+}$ and $\mathrm{SiO}_{4}^{2-}$ from the feldspar minerals, which led to the formation of sericite and secondary quartz. Pyrite also occurs as fine to medium euhedral and subhedral grains, together with primary quartz crystals.

Argillic alterations accompanied by silicification reactions are common in the Hashtjin area. The argillic units were formed from the decomposition of feldspars to produce clay minerals. Even though there are no boreholes in the area, the outcrops of argillic alteration are exposed in deep valley cuts down to $500 \mathrm{~m}$ in depth in the northern part of the study area. The presence of kaolinite in the deeper parts of the hypogene section is accompanied by iron oxides and oxyhydroxides (goethite), which are not present in more surficial parts of the alteration zone.

Silicification occurred in the form of veins, veinlets and massive silica precipitations. Silica veins were formed within pyroclastic units and included pyrite mineralization. In contrast, 


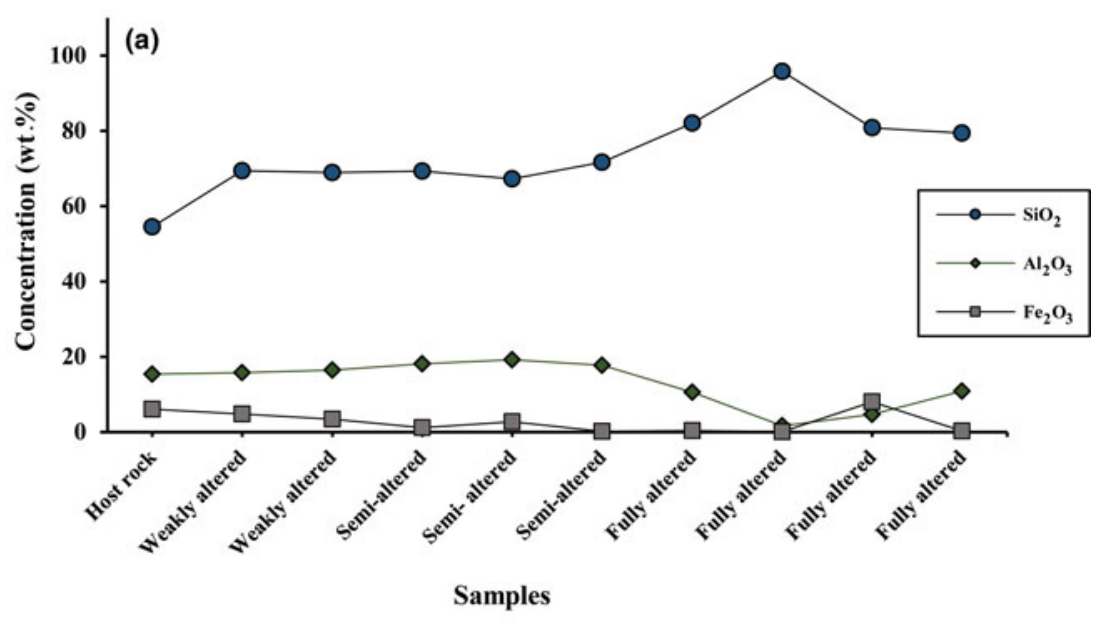

Fig. 7. The concentration values of major oxides in the argillic units of north-west Hashtjin: (a) $\mathrm{Al}_{2} \mathrm{O}_{3}, \mathrm{SiO}_{2}$ and $\mathrm{Fe}_{2} \mathrm{O}_{3}$; (b) $\mathrm{CaO}, \mathrm{Na}_{2} \mathrm{O}, \mathrm{MgO}, \mathrm{K}_{2} \mathrm{O}$ and $\mathrm{P}_{2} \mathrm{O}_{5}$.

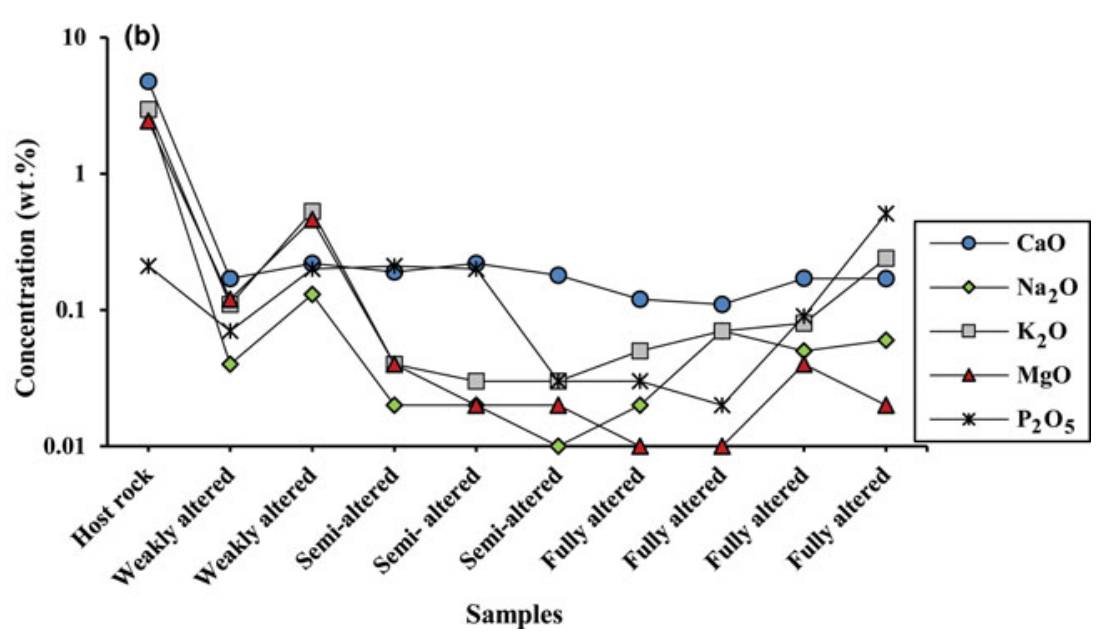

massive silica bodies, referred to as silica ledges, formed by silicification of the rock and are observed in various parts of the area (Fig. 3b).

The XRD analyses of argillic alterations show kaolinite as the main mineralogical phase, together with quartz, cristobalite and anatase as minor constituents. The formation of kaolin from the hydrolysis of aluminosilicates reflects the acidic nature of the hydrothermal fluid (Montoya \& Hemley, 1975). From a geochemical point of view, the argillic alteration occurs at relatively low $\mathrm{pH}$ levels, high water/rock ratios and when the fluid $\mathrm{pH}$ is not in the range of Al mobility (Titley \& Beane, 1981).

Progressive argillic alteration under acidic conditions is known to form kaolinite-dickite-alunite assemblages, which result from acid-sulfate waters due to the conversion of $\mathrm{H}_{2} \mathrm{~S}$ into $\mathrm{H}_{2} \mathrm{SO}_{4}$ in the vadose zone (Ece et al., 2008; Pirajno, 2009). However, the lack of alunite and dickite in the study area can be attributed to the low $\mathrm{H}_{2} \mathrm{~S}$ content of the hydrothermal fluid in the environment and the relatively low formation temperature.

The presence of pseudomorphic goethite produced after pyrite in surficial parts of the study area shows the occurrence of a partial supergene zone overprinting the hydrothermal alteration. During the supergene stage, Fe-sulfide minerals such as pyrite reacted with oxygenated waters to produce reactive acid-sulfate waters (Bigham \& Nordstrom, 2000) that played an important role in the alteration of the parent rocks. These supergene acidic fluids led to further alteration and intensified the grade of kaolinization in the parent rock.

\section{Geochemistry}

Major and minor elements

Based on the varying degree of alteration and changes in colour, a range of samples were selected for geochemical study. The intensity of alteration was also determined based on XRD analysis and petrographic evaluations. The pyroclastic host rock consists mainly of $\mathrm{SiO}_{2}, \mathrm{Al}_{2} \mathrm{O}_{3}$ and $\mathrm{Fe}_{2} \mathrm{O}_{3}$ (54.5, 15.0 and 6.05 wt.\%, respectively; Table 1). The altered samples are enriched in $\mathrm{SiO}_{2}$ and depleted in $\mathrm{Al}_{2} \mathrm{O}_{3}$ and $\mathrm{Fe}_{2} \mathrm{O}_{3}$ compared to the parent rocks (73.9, 13.0 and 2.71 wt.\% for $\mathrm{SiO}_{2}, \mathrm{Al}_{2} \mathrm{O}_{3}$ and $\mathrm{Fe}_{2} \mathrm{O}_{3}$ respectively; Table 1, Fig. 7a). Alkali and alkaline earth element oxides $(\mathrm{CaO}$, $\mathrm{Na}_{2} \mathrm{O}, \mathrm{MgO}$ and $\mathrm{K}_{2} \mathrm{O}$ ) have been depleted in the altered rocks compared to the host rock (Fig. 7b). The sum of $\mathrm{TiO}_{2}, \mathrm{P}_{2} \mathrm{O}_{5}$ and $\mathrm{MnO}$ in the host rock and argillic unit is $\sim 1 \mathrm{wt} . \%$ of the total major oxides (Table 1). The abundances of lithophile and trace elements except for $\mathrm{Sr}, \mathrm{Zr}, \mathrm{Ba}$ and $\mathrm{V}$ in the studied samples are $<100 \mathrm{ppm}$ (Table 2). Sr, Zr, Ba and V show higher concentrations and are significantly enriched in the argillic zones compared to the rock (Fig. 8a-c). The highly altered samples (K03 and K09) have the highest concentrations of $\mathrm{Sr}$. The $\mathrm{Zr} / \mathrm{Hf}$ ratio range of $35.4-40.5$ is comparable with that of the unaltered ignimbrite. In addition, the $\mathrm{Nb} / \mathrm{Ta}$ ratio ranges between 12.8 and 16.8 .

\section{REES and $Y$}

In the argillic samples, the total REE ( $\Sigma R E E$ ) values range between 15.6 and $316 \mathrm{ppm}$, and the highest values correspond to the 
Table 2. The REE and trace element concentrations (ppm) of the ignimbritic parent rock and the argillic samples of the north-west Hashtjin area using the ICP-MS method.

\begin{tabular}{|c|c|c|c|c|c|c|c|c|c|c|}
\hline & Ignimbrite & Weakly altered & Weakly altered & Semi-altered & Semi-altered & Fully altered & Fully altered & Semi-altered & Fully altered & Fully altered \\
\hline Sample no. & $\mathrm{K} 00$ & K01 & K02 & K03 & K04 & K05 & K06 & K07 & K08 & K09 \\
\hline La & 24.1 & 27 & 39.3 & 29.8 & 37.4 & 20.8 & 2.9 & 11.8 & 27.2 & 89.1 \\
\hline $\mathrm{Ce}$ & 48.6 & 50 & 74.8 & 56.1 & 72.2 & 35.3 & 5.8 & 20.1 & 33.2 & 138 \\
\hline $\operatorname{Pr}$ & 5.4 & 5.3 & 8.04 & 7.23 & 8.32 & 3.26 & 0.61 & 1.99 & 3.19 & 12.05 \\
\hline $\mathrm{Nd}$ & 20.1 & 18 & 28.7 & 33.3 & 32.3 & 9.9 & 2.1 & 6.5 & 10.4 & 35.5 \\
\hline $\mathrm{Sm}$ & 4.04 & 2.7 & 5.43 & 7.11 & 6.22 & 1.9 & 0.38 & 1.77 & 2.04 & 5.36 \\
\hline $\mathrm{Eu}$ & 1.1 & 0.53 & 1.35 & 1.32 & 1.73 & 0.23 & 0.05 & 0.29 & 0.43 & 1 \\
\hline $\mathrm{Gd}$ & 14.7 & 17.2 & 17.7 & 27.6 & 19.3 & 11.8 & 2 & 18.5 & 27 & 30.7 \\
\hline $\mathrm{Tb}$ & 0.69 & 0.39 & 1.18 & 0.73 & 0.88 & 0.33 & 0.08 & 0.48 & 0.23 & 0.46 \\
\hline Dy & 3.93 & 2.68 & 8.46 & 3.49 & 4.03 & 1.87 & 0.51 & 3.31 & 1.59 & 1.76 \\
\hline $\mathrm{Ho}$ & 0.82 & 0.57 & 1.92 & 0.67 & 0.64 & 0.36 & 0.11 & 0.74 & 0.38 & 0.29 \\
\hline $\mathrm{Er}$ & 2.55 & 1.94 & 6.41 & 2.24 & 1.94 & 1.21 & 0.39 & 2.51 & 1.5 & 0.94 \\
\hline $\mathrm{Tm}$ & 0.35 & 0.32 & 0.95 & 0.33 & 0.26 & 0.19 & 0.07 & 0.43 & 0.26 & 0.14 \\
\hline $\mathrm{Yb}$ & 2.46 & 2.16 & 6.67 & 2.2 & 1.86 & 1.37 & 0.53 & 3.17 & 1.85 & 0.97 \\
\hline Lu & 0.39 & 0.34 & 1.02 & 0.34 & 0.27 & 0.21 & 0.08 & 0.5 & 0.28 & 0.16 \\
\hline V & 153 & 130 & 84 & 295 & 96 & 29 & 17 & 33 & 162 & 90 \\
\hline $\mathrm{Cr}$ & 70 & 60 & 40 & 60 & 40 & 10 & 10 & 10 & 90 & 130 \\
\hline $\mathrm{Cu}$ & 33 & 8 & 12 & $<5$ & $<5$ & 7 & $<5$ & $<5$ & 77 & 10 \\
\hline $\mathrm{Zn}$ & 46 & $<5$ & 26 & $<5$ & 6 & 5 & 5 & 11 & 22 & 9 \\
\hline Y & 22.7 & 14.8 & 56.8 & 17.5 & 16.4 & 10.9 & 3.6 & 20.4 & 11.7 & 6.2 \\
\hline $\mathrm{Pb}$ & $<5$ & $<5$ & 25 & 39 & 26 & $<5$ & $<5$ & 7 & 36 & 42 \\
\hline Sn & 1 & 3 & 3 & 2 & 7 & 4 & 2 & 7 & 17 & 1 \\
\hline $\mathrm{Tl}$ & $<0.5$ & $<0.5$ & $<0.5$ & 0.5 & $<0.5$ & $<0.5$ & $<0.5$ & $<0.5$ & $<0.5$ & $<0.5$ \\
\hline $\mathrm{Ga}$ & 14.7 & 17.2 & 17.7 & 27.6 & 19.3 & 11.8 & 2 & 18.5 & 27 & 30.7 \\
\hline W & 5 & 6 & 4 & 3 & 4 & 4 & 2 & 3 & 2 & 2 \\
\hline $\mathrm{Rb}$ & 93.6 & 7.3 & 19.2 & 3.9 & 3 & 7.7 & 12 & 4 & 6.2 & 8.5 \\
\hline $\mathrm{Sr}$ & 312 & 699 & 681 & 1595 & 961 & 120.5 & 32.3 & 32.1 & 477 & 2990 \\
\hline Cs & 1.5 & 1.21 & 1.81 & 1.87 & 1.54 & 4.66 & 6.42 & 4.25 & 3.03 & 3.76 \\
\hline $\mathrm{Ba}$ & 429 & 99.8 & 217 & 178 & 134 & 43.5 & 38.8 & 27.9 & 154.5 & 468 \\
\hline $\mathrm{Zr}$ & 206 & 300 & 319 & 288 & 372 & 449 & 216 & 675 & 291 & 224 \\
\hline $\mathrm{Nb}$ & 13.8 & 22.5 & 24 & 22.4 & 27.6 & 37.3 & 37 & 60.5 & 21.7 & 19 \\
\hline $\mathrm{Hf}$ & 5.1 & 7.4 & 8.3 & 7.6 & 9.6 & 11.6 & 6.1 & 17.3 & 7.3 & 5.9 \\
\hline Th & 8.35 & 13.6 & 16.6 & 12.7 & 18.5 & 14.75 & 4.05 & 26.1 & 21.5 & 26.6 \\
\hline$U$ & 2.09 & 3.08 & 3.41 & 2.58 & 3.54 & 5.02 & 1.58 & 4.67 & 6.98 & 3.6 \\
\hline $\mathrm{Ta}$ & 1 & 1.7 & 1.8 & 1.7 & 2 & 2.7 & 2.2 & 3.7 & 1.7 & 1.3 \\
\hline LOI & 8.64 & 7.05 & 7.25 & 8.21 & 8.25 & 5.46 & 1.77 & 7.55 & 4.55 & 6.23 \\
\hline Total & 98.7 & 98.2 & 98.3 & 98.1 & 98.7 & 99.5 & 100.5 & 98.4 & 99.5 & 99 \\
\hline
\end{tabular}

intensely altered samples (K06 and K09) (Table 2). The light REEs (LREEs; La, Ce, Pr, Nd, Sm, Eu and Gd) are significantly enriched compared to their heavy REE (HREE) counterparts (T, Dy, Ho, Er, Tm, Yb and Lu) (Fig. 9a,b). The $\Sigma R E E$ in the ignimbritic parent rock is $129 \mathrm{ppm}$, whereas the averages of the LREEs and HREEs in this unit are 11.2 and $119 \mathrm{ppm}$, respectively.

The chondrite-normalized REE patterns of the altered samples and pyroclastic parent rock display fractionation of LREEs over the HREEs and a negative Eu anomaly (Fig. 9a,b). The parameters used to evaluate REE fractionation are (Rollinson, 1993):

$$
(\mathrm{La} / \mathrm{Yb})_{\mathrm{N}}=\left(\left(\mathrm{La}_{\text {Sample }} / \mathrm{La}_{\text {Chondrite }}\right) /\left(\mathrm{Yb}_{\text {Sample }} / \mathrm{Yb}_{\text {Chondrite }}\right)\right)
$$

$$
\begin{aligned}
& (L R E E / H R E E)_{\mathrm{N}} \\
& \quad=\left((L R E E / H R E E)_{\text {Sample }}\right) /\left(\left(L R E E / H R E E_{\text {Chondrite }}\right)\right)
\end{aligned}
$$

The $(\mathrm{La} / \mathrm{Yb})_{\mathrm{N}}$ in the altered samples ranges from 2.5 to 62.1 (6.6 in the parent rock) and the (LREE/HREE) $)_{\mathrm{N}}$ values range between 2.0 and 20.8 (3.6 in the parent rock). In addition, the $\mathrm{La} / \mathrm{Lu}$ values of the altered samples increase considerably relative to the parent rock (Fig. 9b), suggesting that the LREE content increases in the fully altered samples, while the HREE content remains constant in these samples. Finally, the $\mathrm{Y} / \mathrm{Ho}$ ratio in the argillic samples varies between 21.4 and 32.7 (28.0 in the host ignimbrite) (Fig. 10), with the lowest values of this ratio corresponding to the intensely altered samples. The $\mathrm{Ce}$ and $\mathrm{Eu}$ anomalies were estimated using the approaches of Taylor \& McLenan (1985) and Bau \& Dulski (1996).

$$
\begin{gathered}
\mathrm{Eu} / \mathrm{Eu}^{*}=\left(\mathrm{Eu}_{\mathrm{N}}\right) / \sqrt{ }\left(\left(\mathrm{Sm}_{\mathrm{N}}\right) \times\left(\mathrm{Gd}_{\mathrm{N}}\right)\right)(\text { Taylor \& McLenan, 1985) } \\
\mathrm{Ce} / \mathrm{Ce} e^{*}=(\mathrm{Ce} /(0.5 \mathrm{La}+0.5 \mathrm{Pr}))_{\mathrm{N}}(\text { Bau \& Dulski, 1996) }
\end{gathered}
$$

The Ce anomaly in the altered samples varies between 0.71 and 0.98 ( 0.96 in the host ignimbrites), and the Eu anomaly ranges from 0.15 to 0.48 ( 0.43 in the host ignimbrites).

\section{Discussion}

\section{Types of alteration contributing to kaolinization}

Three main indicators have been used to determine the type of alteration responsible for kaolinization of the lithological units of the study area. $\mathrm{TiO}_{2}$ was considered as the first geochemical indicator to estimate the origin of the fluids. The investigations conducted revealed that $\mathrm{TiO}_{2}$ contents of $<1$ wt.\% represent the hypogene kaolin and $\mathrm{TiO}_{2}$ contents of $>1$ wt. $\%$ represent a supergene origin of the fluids (Maiza et al., 2003). With respect to the $\mathrm{TiO}_{2}$ values of the studied 

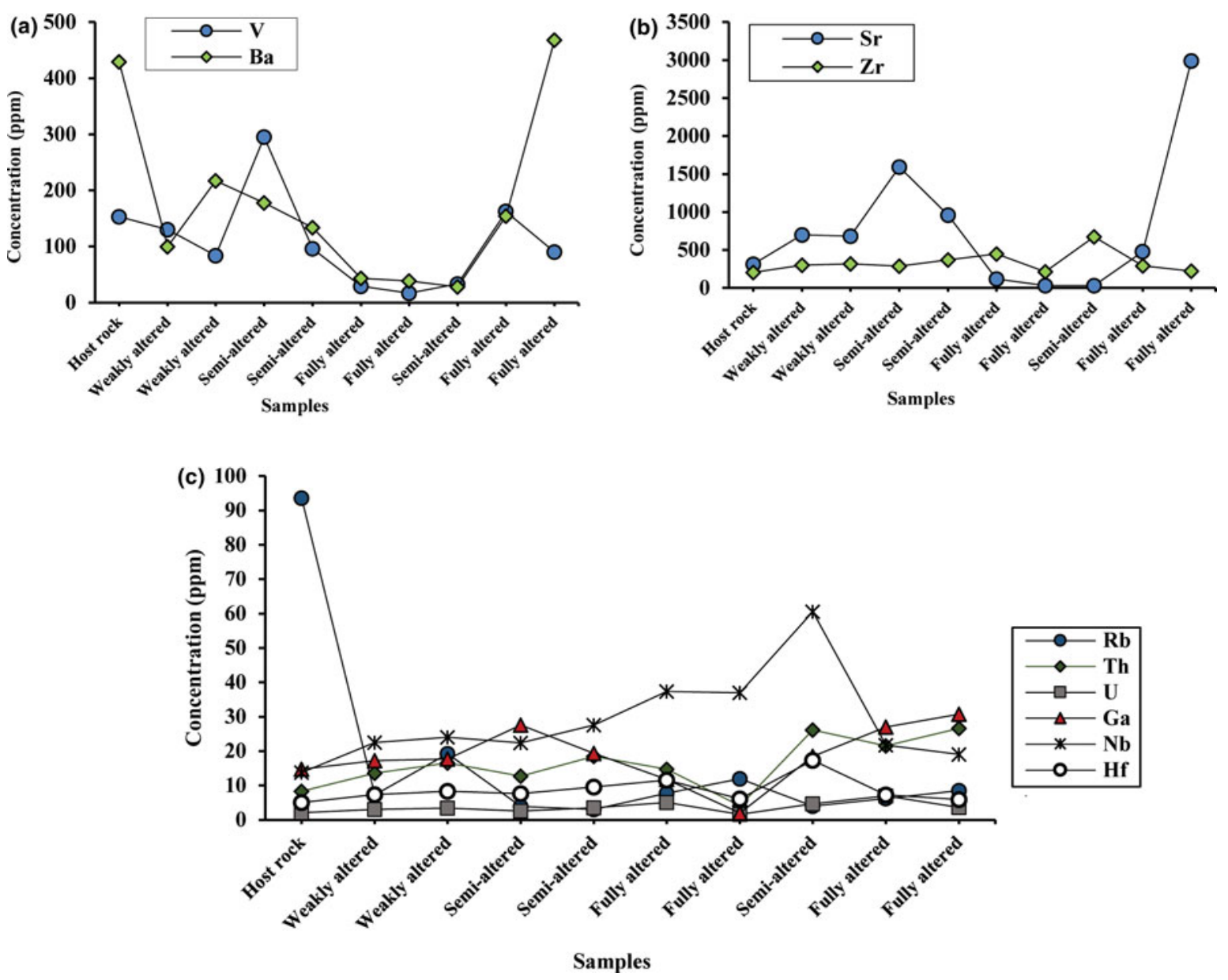

Fig. 8. The concentration values of trace elements in the argillic units of north-west Hashtjin: (a) V and $\mathrm{Ba}$; (b) $\mathrm{Zr}$ and $\mathrm{Sr}$; (c) Rb, Th, U, Ga, Nb and Hf.

samples obtained (0.55-1.10 wt.\%) (Table 1), both hypogene and supergene fluids have clearly affected the kaolinization of the ignimbritic parent rock in the area.

$\mathrm{Br}+\mathrm{Sr}$ and $\mathrm{Ce}+\mathrm{Y}+\mathrm{La}$ concentrations also provide information on the nature of the fluid-rock interactions giving rise to the studied kaolin deposits. The binary plot of $\mathrm{Br}+\mathrm{Sr} v s \mathrm{Ce}+\mathrm{Y}+\mathrm{La}$ for the analysed samples reveals the effects of both supergene and hypogene fluids in the formation of the studied kaolins (Fig. 11a). The high values of $\mathrm{Br}+\mathrm{Sr}$ are related to hypogene kaolin deposits, whereas $\mathrm{Ce}+\mathrm{Y}+\mathrm{La}$ contents indicate a supergene origin (Dill et al., 1997).

The third characteristic used in this study is represented by the concentrations of $\mathrm{Ti}+\mathrm{Fe}$ and $\mathrm{Ce}+\mathrm{Nb}$, whereby high contents also support a supergene origin (Dill et al., 1997). The $\mathrm{Ti}+\mathrm{Fe}$ vs $\mathrm{Ce}+\mathrm{Nb}$ plot for the studied samples also confirms the role of both hypogene and supergene fluids in the formation of the studied kaolin samples (Fig. 11b).

\section{Fluid-rock interactions and REE patterns}

Figure 9 displays the REE patterns of argillic samples and the host rock of the study area normalized to the chondrite composition (Anders \& Grevesse, 1989). The parent pyroclastic rock is enriched in LREEs and has a $\mathrm{La} / \mathrm{Lu}$ ratio of 5.1, whereas, in the argillic unit, an enrichment of LREEs relative to HREEs is observed, with a $\mathrm{La} / \mathrm{Lu}$ ratio of $2.2-27.6$ and a tetrad effect of $\mathrm{T}_{3}$ and $\mathrm{T}_{4}$.
The fractionation of LREEs from HREEs in the altered samples is known to occur in acidic $\mathrm{pH}$, especially at the $\mathrm{pH}$ ranges below 5.1 (Leybourne et al., 2006). In general, REEs form complexes with $\mathrm{SO}_{4}^{2-}$ at low $\mathrm{pH}$. The $(\mathrm{La} / \mathrm{Yb})_{\mathrm{N}}$ and $(L R E E / H R E E)_{\mathrm{N}}$ values of the pyroclastics in the study area suggest that the $\mathrm{pH}$ of the hydrothermal fluids varied due to the presence of $\mathrm{SO}_{4}^{2-}$ produced by hypogene processes, and these changes might be considered as a reason for the fractionation of the REEs. The REE ions, except for $\mathrm{Ce}$ and $\mathrm{Eu}$, are stable in their trivalent states, and thus they have similar physicochemical characteristics. Additional oxidation states are possible for Ce and Eu (Rollinson, 1993), which may affect their fractionation ratios. Eu can appear as $\mathrm{Eu}^{2+}$, which replaces $\mathrm{Ca}^{2+}$ in plagioclase or can be oxidized to $\mathrm{Eu}^{3+}$ during alteration at low temperatures (e.g. $\sim 100^{\circ} \mathrm{C}$ ) in an oxidizing environment (Sverjensky, 1984). In addition, the relatively negative Eu anomaly $(0.15-0.48)$ in the altered pyroclastics of the Hashtjin area may represent fractional crystallization of the magma and separation of plagioclase (Lackschewitz et al., 2000). Cerium may also appear as $\mathrm{Ce}^{4+}$, and the fractionation of this element depends on the redox conditions. $\mathrm{Ce}^{4+}$ is less mobile than the remaining $R E E^{3+}$, causing a Ce anomaly during the $R E E^{3+}$ partitioning between fluid and solid. A negative Ce anomaly has been observed in authigenic clays, hydrothermal deposits, nanofossil ooze and fish debris (Plank \& Langmuir, 1998; Picard et al., 2002; Moiroud et al., 2016). In the present study, the weak negative Ce anomaly $(0.72-1.00)$ in the argillic samples of the Hashtjin 


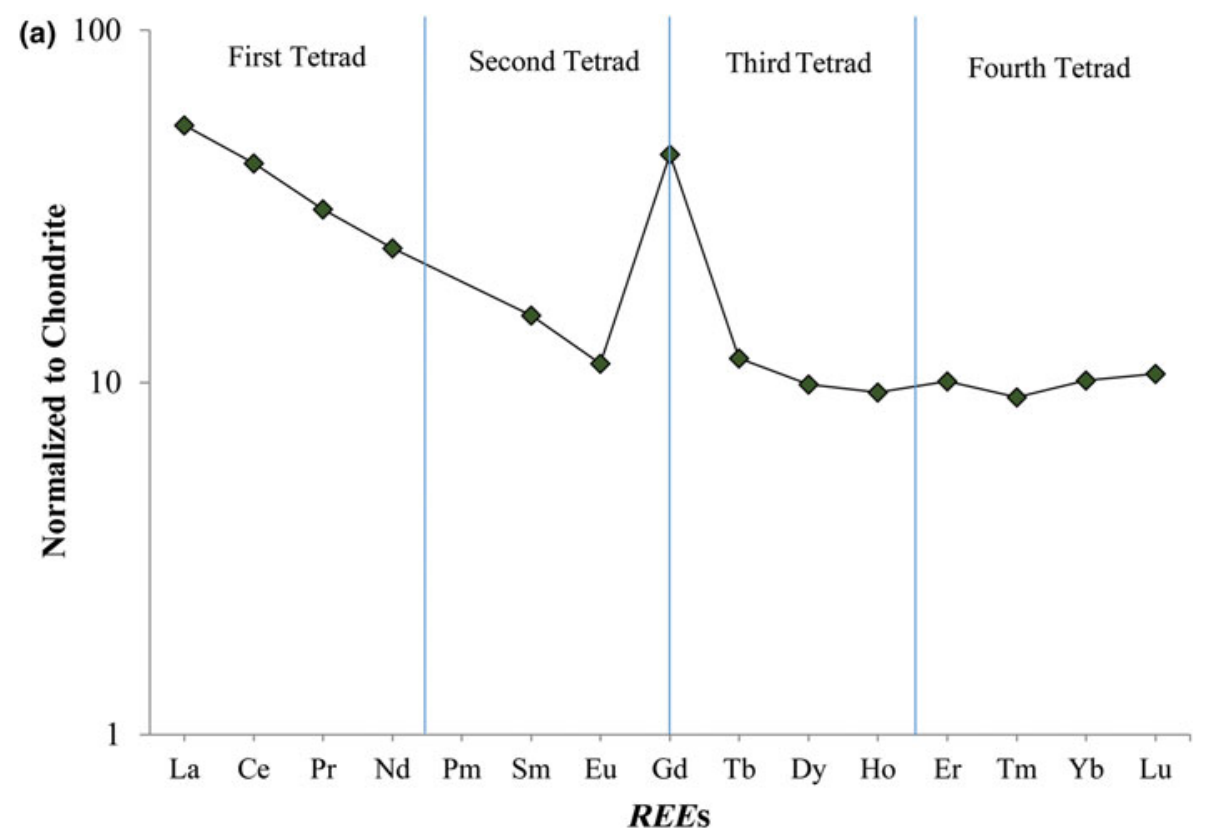

(b)

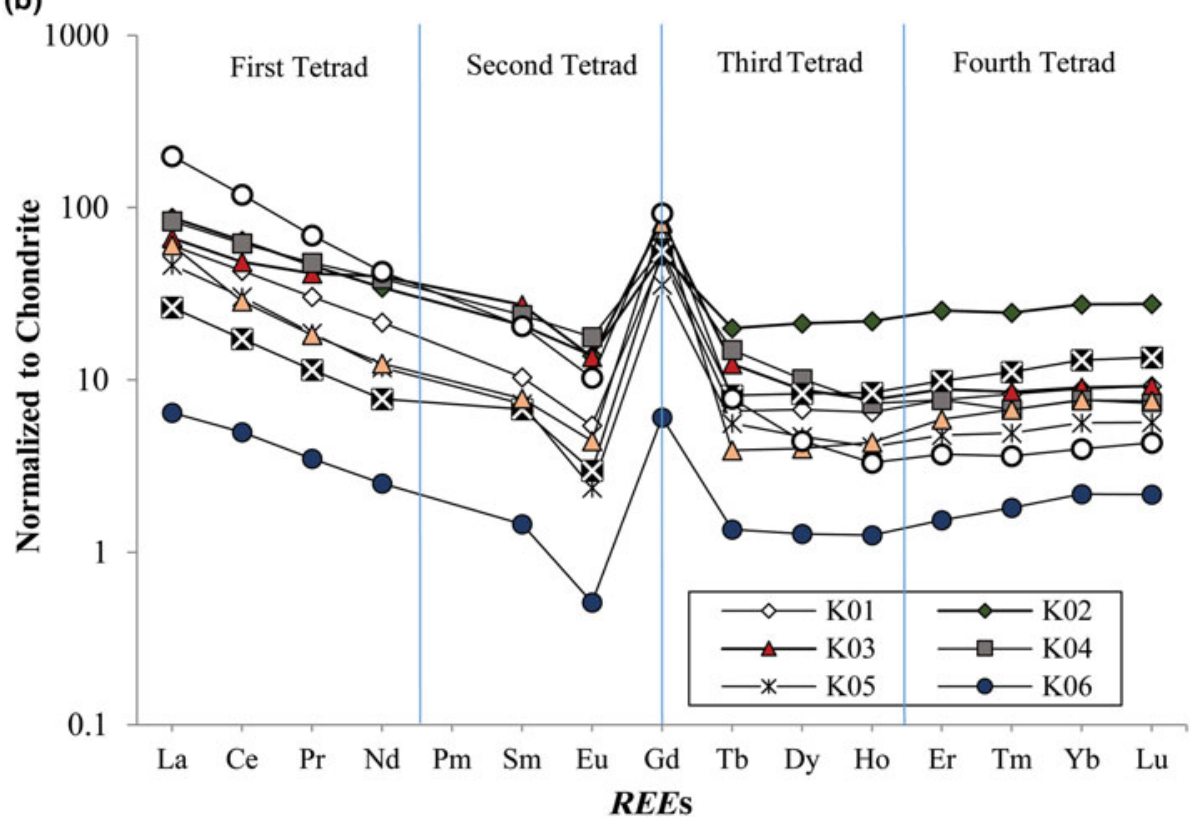

Fig. 9. Chondrite-normalized REE patterns (Anders \& Grevesse, 1989): (a) from the parent rock of north-west Hashtjin argillic alterations; (b) from argillic alterations of north-west Hashtjin. area is probably related to supergene alteration. The high coefficient of determination between $\mathrm{Eu} / \mathrm{Eu}^{*}$ and $\mathrm{Mn}$ and between $\mathrm{Ce} / \mathrm{Ce}^{*}$ and $\mathrm{Mn}\left(r^{2}=1\right)$ suggests that these elements are controlled by Mn-oxide minerals formed under oxidizing conditions (Amakawa, 1991; Bau et al., 2014).

The parent volcanic rocks of the Hashtjin area have Y/Ho ratios that are comparable to chondrite and show CHARAC behaviour. In contrast, the $\mathrm{Y} / \mathrm{Ho}$ ratios of samples affected by argillic alteration show weak non-chondrite behaviour of REEs (Fig. 12). The altered samples plot out of the CHARAC area and towards the field of hydrothermal fluids in the plot of Y/Ho vs Zr/Hf (Fig. 12), suggesting the interaction of fluids and volcanic rocks. The adsorption of Ho by Mn-oxides and the fractionation of $\mathrm{Y}$ and Ho during the alteration probably caused the weak non-chondrite behaviour of the $\mathrm{Y} / \mathrm{Ho}$ ratio. This behaviour is consistent with the high coefficient of determination of Ho with $\mathrm{MnO}\left(r^{2}=0.96\right)$ in ten of the samples.

\section{The tetrad effect}

Table 3 displays the calculated values of $\mathrm{T}_{3}$ and $\mathrm{T}_{4}$ for the parent rock and the altered samples in the study area. Figure $13 \mathrm{a}-\mathrm{e}$ shows chondrite-normalized REE diagrams for the volcanoclastic parent rock and the semi-altered and fully altered argillic (kaolin) samples. The third and fourth tetrad effects are observable in the parent rock and the third tetrad has the form of a W-type tetrad (Fig. 14a), which is attributed to a positive Gd anomaly. $\mathrm{Gd}$ and $\mathrm{Tb}$ positive anomalies are commonly observed in seawaters (De Baar et al., 1985) and are related to the fractionation of $\mathrm{Gd} / \mathrm{Tb}$ due to the change of the $\mathrm{f} 4$ half-filled electron shell 
Fig. 10. The variation in the $\mathrm{Zr} / \mathrm{Hf}, \mathrm{Y} / \mathrm{Ho}$ and $\mathrm{Nb} / \mathrm{Ta}$ ratios in north-west Hashtjin argillic alterations and their ignimbritic host rock.

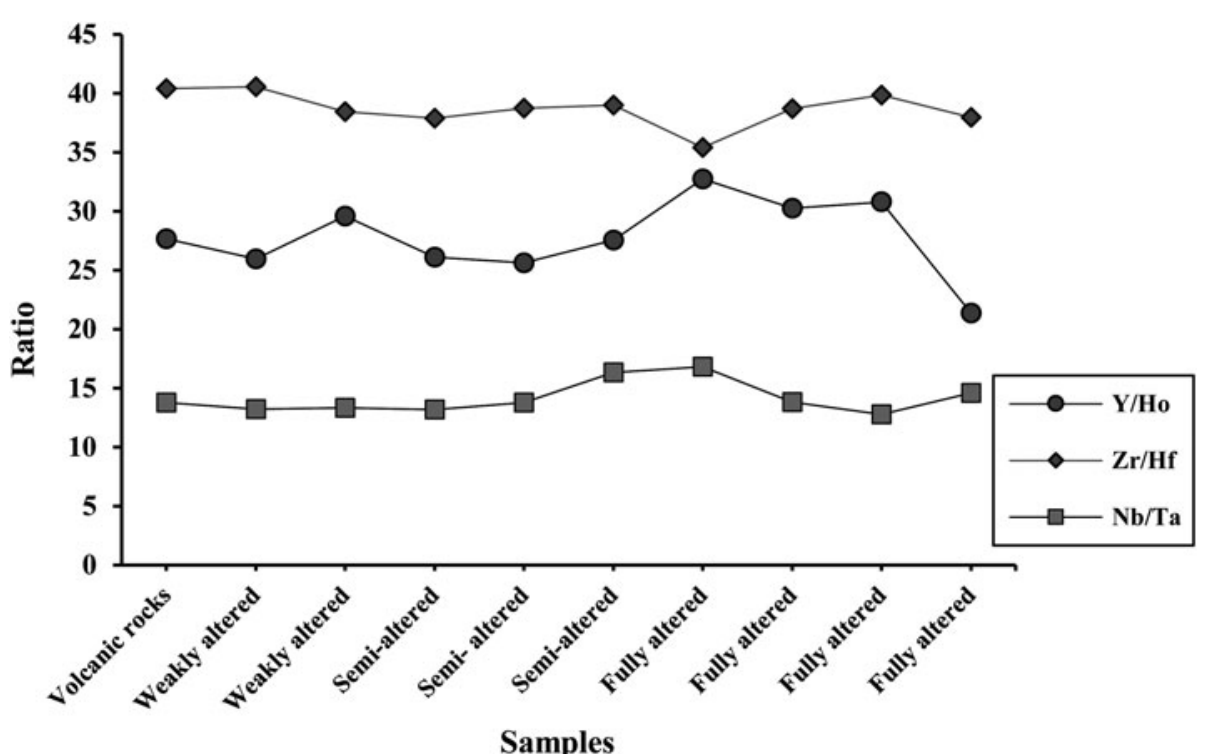

Samples

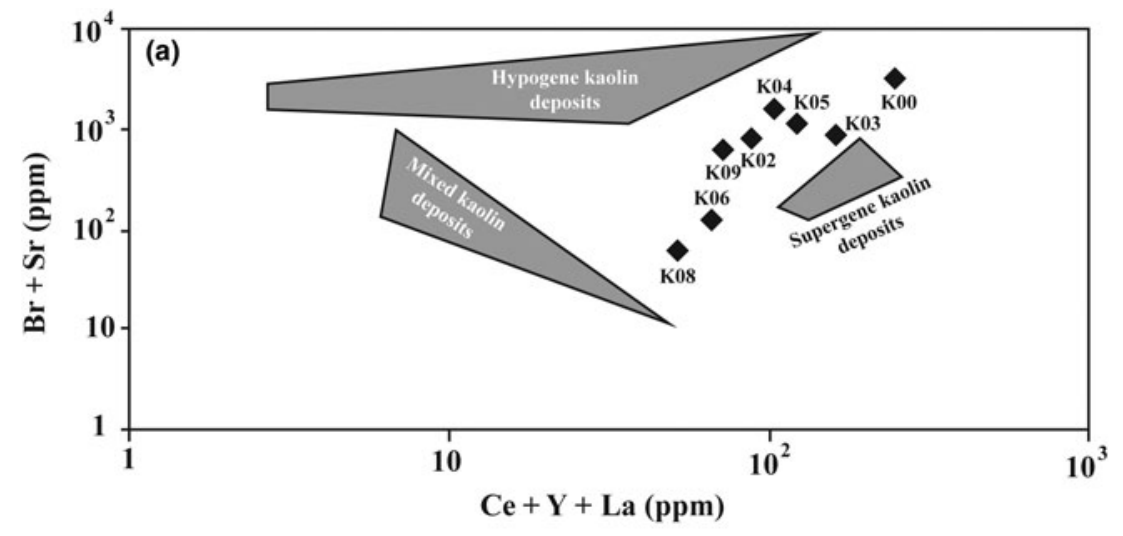

Fig. 11. The position of the studied samples in the binary diagram: (a) $\mathrm{Br}+\mathrm{Sr}$ vs $\mathrm{Ce}+\mathrm{Y}+\mathrm{La}$; (b) $\mathrm{Ti}+\mathrm{Fe}$ vs $\mathrm{Ce}+\mathrm{Nb}$ (Dill et al., 1997).

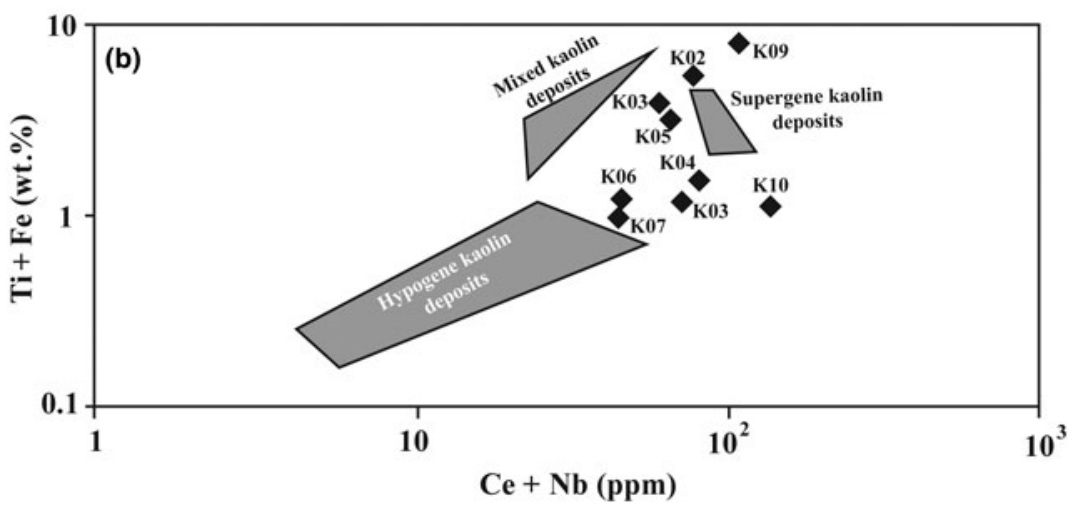

(De Baar et al., 1985). It is probable that the emplacement of pyroclastics in a marine environment and the interaction with seawater gave rise to the Gd anomaly. This explains the occurrence of the tetrad effect in the ignimbritic parent rock, which was subsequently enhanced by hypogene hydrothermal alteration.

The altered samples show a W-type effect in the third tetrad (Fig 13b-e). In the W-type tetrad, the Dy and $\mathrm{Yb}$ appear in descending order, whereas Er appears in the ascending trend
(Masuda et al., 1987). The values of the third and fourth tetrads are $0.01-0.50$ and $0.01-2.90$, respectively. Comparing the tetrad effects between the fully altered sample (K06) and parent ignimbrite (Fig. 14) indicates that the hydrothermal alteration of the parent rock gives rise to more pronounced fourth tetrad effects. The wide range of tetrad effects may result from surface weathering (Masuda \& Akagi, 1989; Mioduski, 1997). The presence of good correlation between the sizes of the tetrads and the intensity 


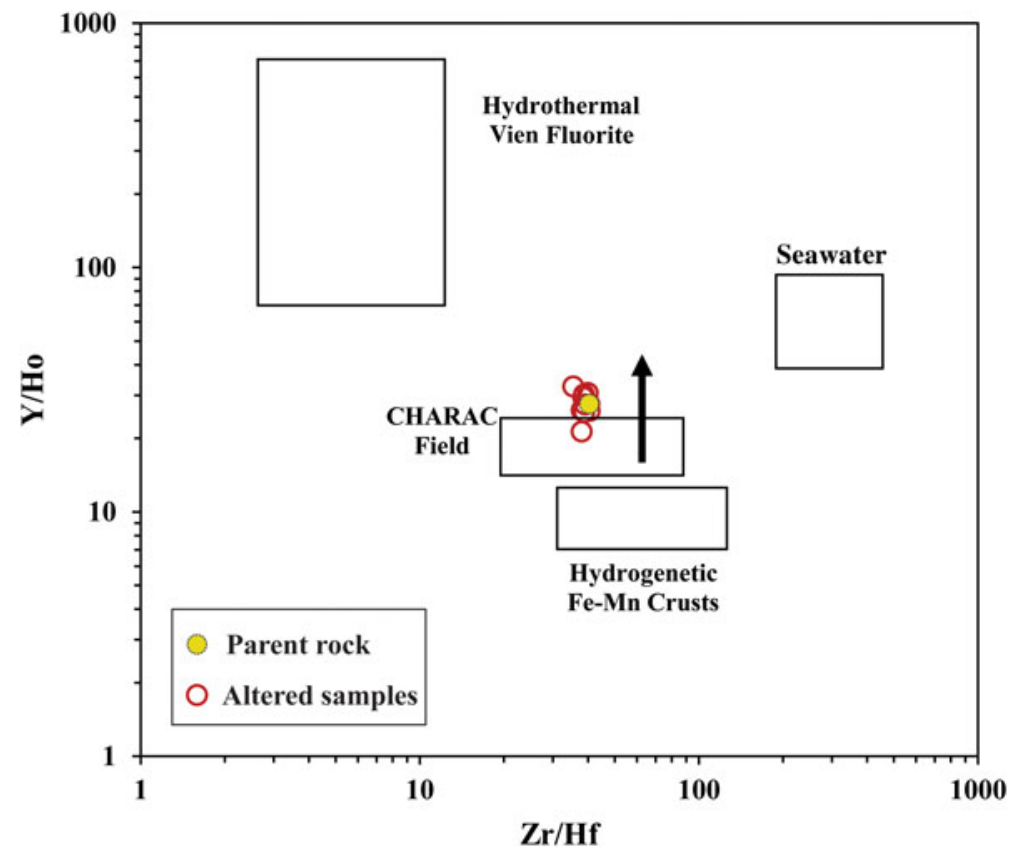

Fig. 12. The $\mathrm{Zr} / \mathrm{Hf}-\mathrm{Y} / \mathrm{Ho}$ diagram (Bau, 1996) representing the plot of altered units and their pyroclastic parent rock of the north-west Hashtjin area.

Table 3. The calculated values of $\mathrm{Y} / \mathrm{Ho}, \mathrm{Zr} / \mathrm{Hf}, \mathrm{LREE} / \mathrm{HREE}, \mathrm{La} / \mathrm{Yb}_{\mathrm{N}}, \mathrm{Eu}^{\star}, \mathrm{Ce}^{\star}, \mathrm{La} / \mathrm{Lu}^{\star}, \mathrm{T}_{3}$ and $\mathrm{T}_{4}$ for the studied samples.

\begin{tabular}{|c|c|c|c|c|c|c|c|c|c|c|}
\hline & Ignimbrite & Weakly altered & Weakly altered & Semi-altered & Semi-altered & Fully altered & Fully altered & Semi-altered & Fully altered & Fully altered \\
\hline Sample no. & K00 & K01 & $\mathrm{K} 02$ & $\mathrm{~K} 03$ & K04 & K05 & K06 & K07 & K08 & K09 \\
\hline $\mathrm{Y} / \mathrm{Ho}$ & 27.68 & 25.96 & 29.58 & 26.12 & 25.63 & 30.28 & 32.73 & 27.57 & 30.79 & 21.38 \\
\hline $\mathrm{Zr} / \mathrm{Hf}$ & 40.39 & 40.54 & 38.43 & 37.89 & 38.75 & 38.71 & 35.41 & 39.02 & 39.86 & 37.97 \\
\hline LREE/HREE & 3.14 & 4.14 & 1.91 & 4.97 & 5.38 & 4.31 & 2.20 & 1.77 & 5.33 & 17.72 \\
\hline $\mathrm{La} / \mathrm{Yb}_{\mathrm{N}}$ & 3.14 & 6.78 & 3.20 & 7.35 & 10.91 & 8.24 & 2.97 & 2.02 & 7.97 & 49.82 \\
\hline $\mathrm{Eu}^{\star}$ & 0.43 & 0.24 & 0.42 & 0.28 & 0.48 & 0.15 & 0.17 & 0.15 & 0.18 & 0.24 \\
\hline $\mathrm{Ce}^{\star}$ & 0.99 & 0.95 & 0.96 & 0.90 & 0.95 & 0.93 & 1.00 & 0.92 & 0.72 & 0.89 \\
\hline $\mathrm{La} / \mathrm{Lu}^{\star}$ & 5.09 & 9.21 & 27.64 & 9.21 & 7.32 & 5.69 & 2.17 & 13.55 & 7.59 & 4.34 \\
\hline$T_{3}$ & 0.01 & 0.01 & 0.00 & 0.01 & 0.01 & 0.03 & 0.57 & 0.01 & 0.01 & 0.01 \\
\hline $\mathrm{T}_{4}$ & 0.08 & 0.13 & 0.01 & 0.11 & 0.15 & 0.33 & 2.93 & 0.07 & 0.21 & 0.53 \\
\hline
\end{tabular}

of alteration (Fig. 14) also suggests that this may have occurred due to the interaction of hydrothermal fluids with the parent rock.

\section{The origin of the tetrad effect in the argillic pyroclastics of the Hashtjin area}

The extensive argillic alteration zones in the pyroclastics of the Hashtjin area are attributed to the circulation of acid sulfate-rich fluids, which originated as hydrothermal fluids in the hypogene zone and were subsequently overprinted with the oxidation of pyrite in the supergene zone. From a geochemical point of view, the argillic alteration occurred under relatively low- $\mathrm{pH}$ conditions and high water/rock ratios (Titley \& Beane, 1981). Such alteration is usually developed when the fluid $\mathrm{pH}$ is not in the range of $\mathrm{Al}$ mobility, with kaolinite precipitation in the argillic zone indicating that the $\mathrm{pH}$ decreased to $\sim 4.5$ under supergene conditions (Dill et al., 2015).

These acid fluids altered the aluminosilicate minerals of the precursor rocks. In brittle and fractured zones, the advanced argillic alteration formed white kaolin bodies (Fig. 3c). The weak $\mathrm{W}$-type tetrad effect in the chondrite-normalized samples probably resulted from posterior hydrothermal activity (Monecke et al., 2007). The intensity of the $\mathrm{T}_{4}$ effect was enhanced with the increasing degree of alteration at higher water/rock ratios in the supergene zone.

The weak non-chondrite behaviour of $\mathrm{Y}$ and $\mathrm{Ho}$ in the altered samples and the lack of a good correlation between $\mathrm{T}_{3}$ and $\mathrm{T}_{4}$, as well as the low $\mathrm{Y} / \mathrm{Ho}$ ratio, imply that the weak fractionation of $\mathrm{Y}$ from Ho probably occurred under supergene conditions. The variation in the $\mathrm{Y} / \mathrm{Ho}$ ratio $(21.4-32.7)$ in the alteration zone indicates that this ratio lies near the CHARAC field (Bau, 1996).

The evaluation of chondrite-normalized patterns indicates a weak tetrad effect in the logarithmic diagram (Fig. 12). Geochemical processes such as adsorption, fractionation of mineral phases, fluid-rock interactions and REE complexation are the most important factors controlling the tetrad effects in geochemical systems (Bau, 1996; Censi et al., 2007). During hydrothermal alteration, HREEs may be leached and removed by acidic fluids due to the decomposition of HREE-bearing mineral phases (Takahashi et al., 2004). During the interaction of acidic solutions with the host rock, ligands such as $\mathrm{SO}_{4}^{2-}$ and $\mathrm{Cl}^{-}$are consumed because of the increase in the $\mathrm{pH}$ of the solution. Hence, highly acidic hydrothermal fluids are considered to generate large tetrad effect values (Abedini et al., 2020). Such solutions probably produced the intermediate argillic alterations observed in the 
(b)

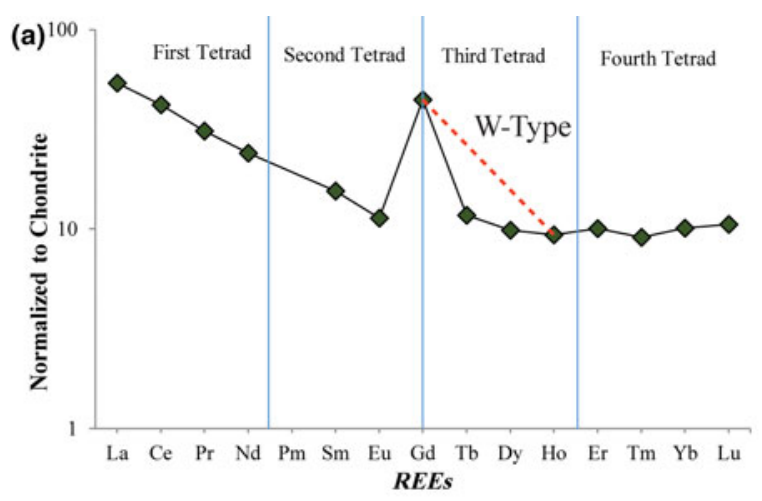

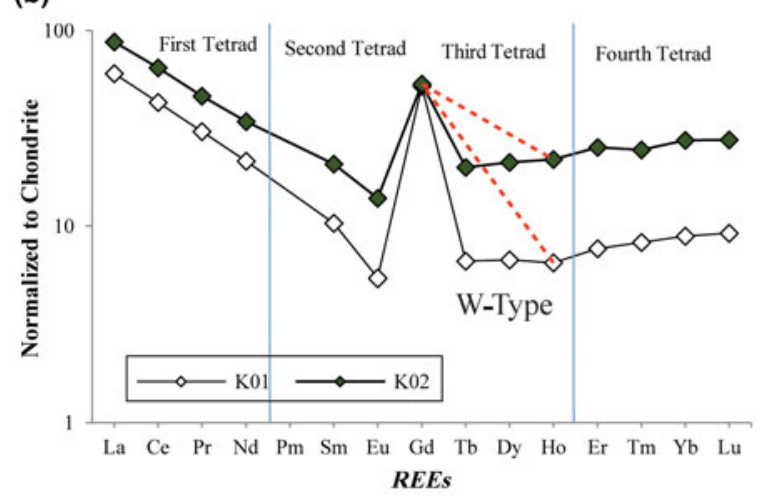

(d)

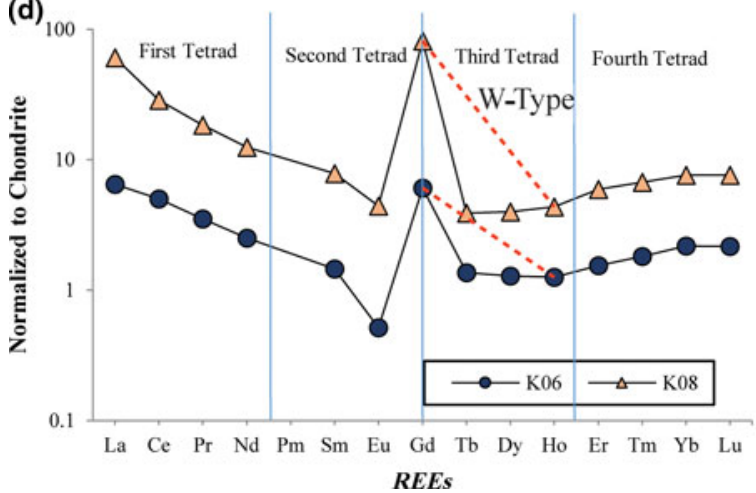

(c) 100

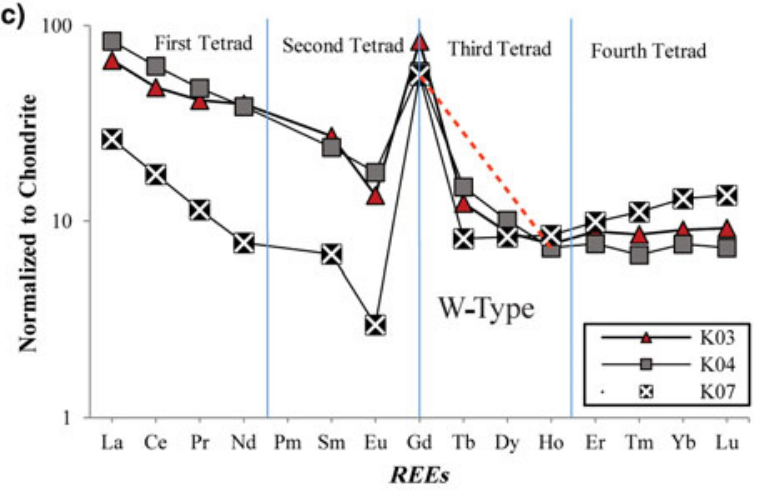

(e)

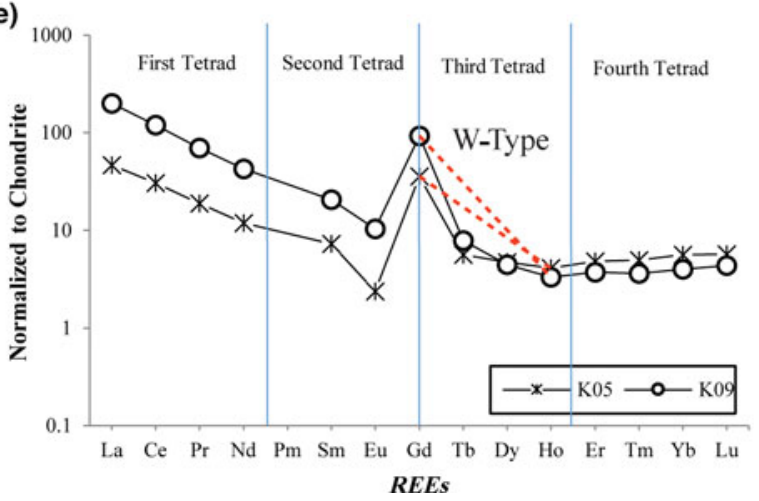

Fig. 13. REE patterns of the studied samples normalized to chondrite (Anders \& Grevesse, 1989) and separated based on the degree of alteration, showing the type of tetrad effect: (a) ignimbritic precursor rock; (b) weakly altered ignimbrite; (c) semi-altered ignimbrite; (d) altered ignimbrite; (e) fully altered ignimbrite (kaolin).

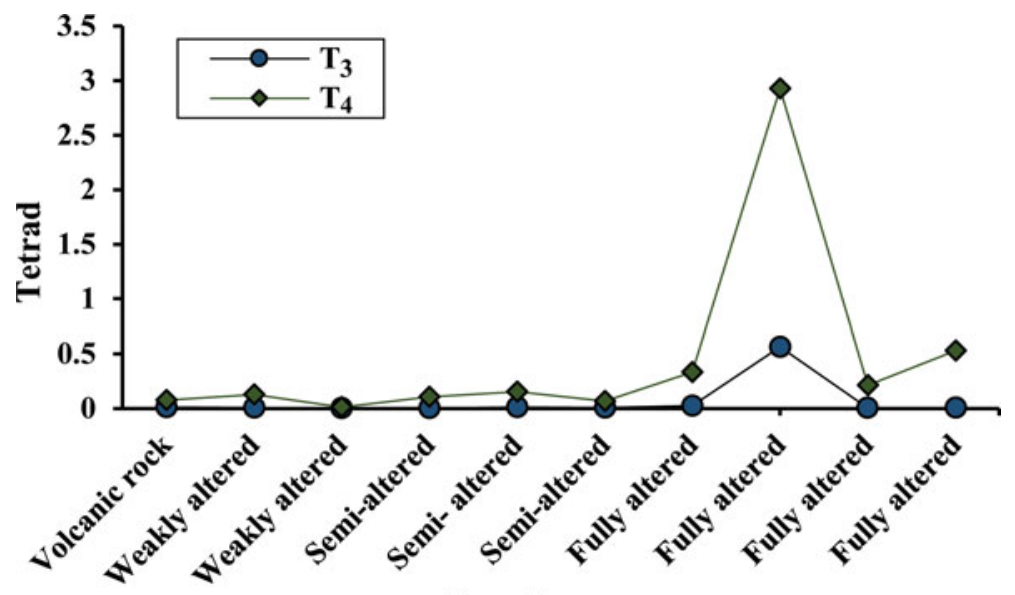



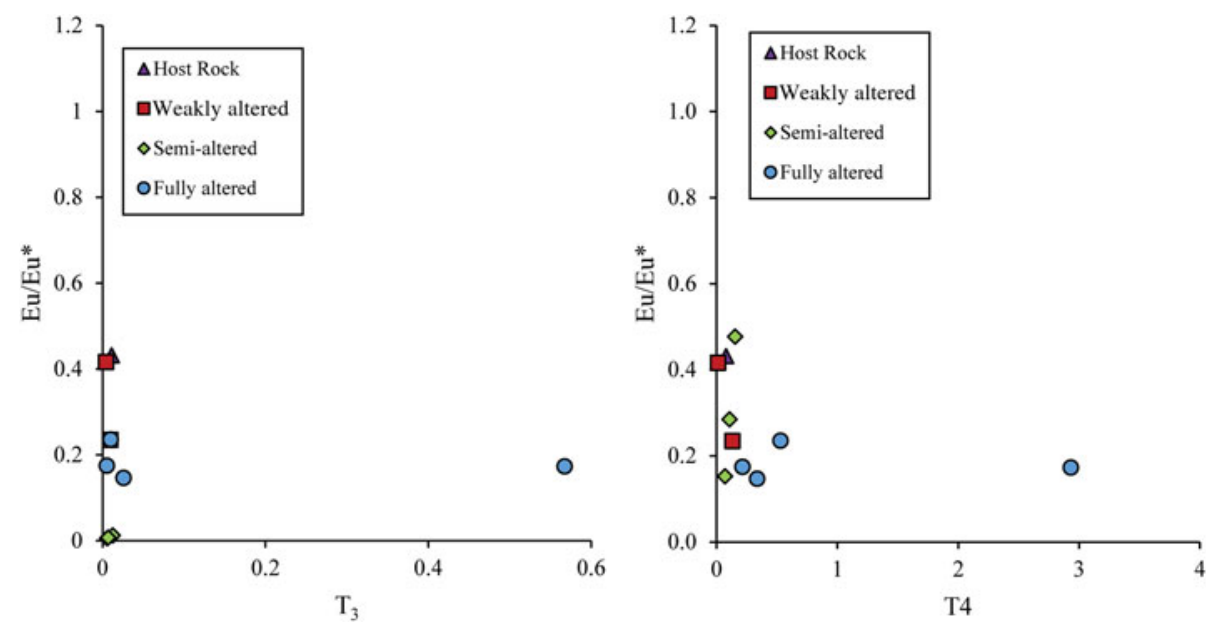

Fig. 15. Binary plots showing $\mathrm{Eu} / \mathrm{Eu}^{\star}$ vs (a) $\mathrm{T}_{3}$ and (b) $\mathrm{T}_{4}$.
Hashtjin area, as is supported by the formation of kaolinite and goethite-bearing assemblages (Dill et al., 2015).

The fractionation of Eu with a tetrad effect from the remaining elements of the group ( $\mathrm{Sm}$ and $\mathrm{Gd}$ ) would lead to the reduction of any Eu anomalies (Feng, 2010), and the projection of $\mathrm{T}_{3}$ and $\mathrm{T}_{4} v s$ $\mathrm{Eu} / \mathrm{Eu}^{*}$ (Fig. 15a,b) shows that this ratio increased only slightly with the increase of the tetrad effect. On the other hand, the weak correlation between $\mathrm{T}_{3}$ and $\mathrm{Ce} / \mathrm{Ce}^{\star}$ in the altered samples is associated with the behaviour of $\mathrm{Ce}$, with a weak anomaly reflecting the redox conditions of hypogene fluids during formation that can be attributed to relatively low oxygen fugacity conditions (Cravero et al., 2001).

\section{Conclusions}

This study of the argillic alteration in the north-west Hashtjin area in north-west Iran led to the following conclusions:

- The pyroclastic precursor rocks (ignimbrites) have been affected by intense hydrothermal and supergene alterations, which have caused noticeable variation in the concentrations of chemical elements. The high $\mathrm{SiO}_{2}$ contents in the altered units represent secondary silicification processes that occurred after argillic alteration and kaolinization.

- The $\mathrm{CaO}, \mathrm{Na}_{2} \mathrm{O}, \mathrm{MgO}$ and $\mathrm{K}_{2} \mathrm{O}$ were considerably depleted during alteration and therefore are considered to have been mobile. In contrast, $\mathrm{Sr}, \mathrm{Zr}$ and Ba were significantly less mobile and enriched compared with the ignimbritic parent rock.

- The chondrite-normalized $R E E$ patterns show an enrichment of LREEs over HREEs. The $(\mathrm{La} / \mathrm{Yb})_{\mathrm{N}}$ values and LREE/HREE ratios of the altered samples are considerably higher compared to the original ignimbrites, suggesting fractionation between LREEs and HREEs.

- The values obtained for $\mathrm{Eu} / \mathrm{Eu}^{\star}$ and $\mathrm{Ce} / \mathrm{Ce}^{\star}$ in the argillic units indicate a weak negative Ce anomaly, attributed to the circulation of oxidizing acidic hydrothermal fluids and a negative $\mathrm{Eu}$ anomaly probably related to leaching of $\mathrm{Eu}$ from plagioclase during the hydrothermal alteration.

- The kaolinized samples have similar Y/Ho variation patterns, whereas the parent rock shows various ratios and only weak non-CHARAC behaviour. On the other hand, the Y/Ho and $\mathrm{Zr} / \mathrm{Hf}$ ratios of the kaolinized samples plot towards the hydrothermal fluid area of the $\mathrm{Y} / \mathrm{Ho}-\mathrm{Zr} / \mathrm{Hf}$ discrimination diagram. The weak non-chondrite behaviour of the $\mathrm{Y} / \mathrm{Ho}$ ratio is probably related to the fractionation of $\mathrm{Y}$ and Ho during the supergene process and adsorption of Ho by Mn-oxides.

- Type $T_{3}$ and $T_{4}$ tetrads are present in the studied samples. The observed fourth tetrad might represent a W-type third tetrad. The generated tetrad in $\mathrm{T}_{3}$ might be due to the high positive anomaly of Gd in the studied samples.

- The W-type tetrad effect produced is attributed to water-rock interactions under the influence of hydrothermal activity.

Acknowledgements. The authors express their appreciation to the reviewers for their technical comments which enhanced the quality of the paper.

Financial support. Thanks go to the authorities of the Research Bureau of the University of Tabriz for providing financial support for this research project.

\section{References}

Abedini A. \& Calagari A.A. (2013) Geochemical characteristics of Kanigorgeh ferruginous bauxite horizon, West-Azarbaidjan province, NW Iran. Periodico di Mineralogia, 82, 1-23.

Abedini A. \& Calagari A.A. (2018) The lanthanide tetrad effect in argillic alteration: an example from the Jizvan District, northern Iran. Acta Geologica Sinica, 92, 1468-1485.

Abedini A., Masoumi R. \& Calagari A.A. (2011) Geochemical features of Kejal kaolin deposit, NW Hashtjin, Ardabil Province. Journal of Economic Geology, 2, 165-181.

Abedini A., Rezaei Azizi M. \& Dill H.G. (2020) The tetrad effect in REE distribution patterns: a quantitative approach to genetic issues of argillic an propylithic alteration zones of epithermal $\mathrm{Cu}-\mathrm{Pb}-\mathrm{Fe}$ deposits related to andesitic magmatism (Khan Kandi District, NW Iran). Journal of Geochemical Exploration, 212, 1-16.

Akagi T., Nakai S., Shimiuzu H. \& Masuda A. (1996) Constraints on the geochemical stage causing tetrad effect in kimuraite: comparative studies on kimuraite and its related rocks, from $\mathrm{REE}$ pattern and $\mathrm{Nd}$ isotope ratio. Geochemical Journal, 30, 139-144.

Akagi T., Shabani M.B. \& Masuda A. (1993) Lanthanide tetrad effect in kimuraite $\left[\mathrm{CaY}_{2}(\mathrm{CO} 3)_{4} \times 6 \mathrm{H}_{2} \mathrm{O}\right]$ : implication for a new geochemical index. Geochimica et Cosmochimica Acta, 57, 2899-2905.

Alavi M. (1996) Tectonostratigraphic synthesis and structural style of the Alborz Mountains system in northern Iran. Geodynamics, 11, 1-33.

Amakawa H. (1991) Isotopic compositions of $\mathrm{Ce}, \mathrm{Nd}$ and $\mathrm{Sr}$ in ferromanganese nodules from the Pacific and Atlantic Oceans, the Baltic and Barents Seas, and the Gulf of Bothnia. Earth and Planetary Science Letters, 105, 554-565.

Anders E. \& Grevesse N. (1989) Abundances of the elements: meteoritic and solar. Geochimica et Cosmochimica Acta, 53, 187-214. 
Barnes H.L. (1997) Geochemistry of Hydrothermal Ore Deposits. John Wiley and Sons, Hoboken, NJ, USA, 972 pp.

Bau M. (1996) Controls on the fractionation of isovalent trace elements in magmatic and aqueous systems: evidence from $\mathrm{Y} / \mathrm{Ho}, \mathrm{Zr} / \mathrm{Hf}$, and lanthanide tetrad effect. Contributions to Mineralogy and Petrology, 123, 323-333.

Bau M. \& Dulski P. (1996) Distribution of yttrium and rare-earth elements in the Penge and Kuruman iron-formations, Transvaal supergroup, South Africa. Precambrian Research, 79, 37-55.

Bau M. \& Knittel U. (1993) Significance of slab-derived partial melts and aqueous fluids for the genesis of tholeiitic and calc-alkaline island-arc basalts: evidence from Mt. Arayat, Philippines. Chemical Geology, 105, 233-251.

Bau M., Koschinsky A., Dulski P. \& Hein J.R. (1996) Comparison of the partitioning behaviours of yttrium, rare earth elements, and titanium between hydrogenetic marine ferromanganese crusts and seawater. Geochimica et Cosmochimica Acta, 60, 1709-1725.

Bau M., Schmidt K., Koschinsky A., Hein J., Kuhn T. \& Usui A. (2014) Discriminating between different genetic types of marine ferro-manganese crusts and nodules based on rare earth elements and yttrium. Chemical Geology, 381, 1-9.

Bigham J.M., \& Nordstrom D.K. (2000) Iron and aluminum hydroxysulfates from acid sulfate waters. Reviews in Mineralogy and Geochemistry, 40, 351-403.

Boulvais P., Ruffet G., Cornichet J. \& Mermet M. (2007) Cretaceous albitization and dequartzification of Hercynian peraluminous granite in the Salvezines Massif (French Pyrénées). Lithos, 93, 89-106.

Buccione R., Mongelli G., Sinisi R. \& Boni M. (2016) Relationship between geometric parameters and compositional data: a new approach to karst bauxites exploration. Journal of Geochemical Exploration, 169, 192-201.

Cantrell, K.J. \& Byrne, R.H. (1987) Rare earth element complexation by carbonate and oxalate ions. Geochimica et Cosmochimica Acta, 51, 597-605.

Censi P., Sprovieri M., Saiano F., Di Geronimo S.I., Larocca D. \& Placenti F. (2007) The behaviour of REEs in Thailand's Mae Klong estuary: suggestions from the Y/Ho ratios and lanthanide tetrad effects. Estuarine, Coastal and Shelf Science, 71, 569-579.

Chen J., Wang, Q., Zhang Q., Carranza E.J.M. \& Wang J. (2018) Mineralogical and geochemical investigations on the iron-rich gibbsitic bauxite in Yongiiang basin, SW China. Journal of Geochemical Exploration, 188, 413-426.

Chen Y.J. \& Zhao Y.C. (1997) Geochemical characteristics and evolution of $R E E$ in the Early Precambrian sediments: evidences from the southern margin of the North China Craton. Episodes, 20, 109-116.

Cravero F., Cravero F. \& Iglesias C. (2001) Genesis and applications of the Cerro Rubio kaolin deposit, Patagonia (Argentina). Applied Clay Science,, 18, 157-172.

De Baar H.J.W., Bacon M.P., Brewer P.G. \& Bruland K.W. (1985) Rare earth elements in the Pacific and Atlantic oceans. Geochimica et Cosmochimica Acta, 49, 1943-1959.

Dill H.G., Bosse H.R., Henning K., Fricke A. \& Ahrendt H. (1997) Mineralogical and chemical variations in hypogene and supergene kaolin deposits in a mobile fold belt the Central Andes of northwestern Peru. Mineralium Deposita, 32, 149-163.

Dill H.G., Dohrmann R., Kaufhold S. \& Cicek G. (2015) Mineralogical, chemical and micromorphological studies of argillic alteration zone of the epithermal gold deposit Ovacik, Western Turkey: tools applied and genetic economic geology. Journal of Geochemical Exploration, 148, 105-127.

Ece Ö.I., Schroeder P.A., Smilley M.J. \& Wampler J.M. (2008) Acid-sulphate hydrothermal alteration of andesitic tuffs and genesis of halloysite and alunite deposits in the Biga Peninsula, Turkey. Clay Minerals, 43, 281-315.

Eftekhar Nejad J. (1980) Tectonic classification of Iran in relation to depositional basins. Journal of Iranian Petroleum Society, 82, 19-28 (in Persian).

Feng J.L. (2010) Behaviour of rare earth elements and yttrium in ferromanganese concretions, gibbsite spots, and the surrounding terrarossa over dolomite during chemical weathering. Chemical Geology, 271, 112-132.

Feng J., Gao S. \& Zhang J. (2011) Lanthanide tetrad effect in ferromanganese concretions and terra rossa overlying dolomite during weathering. Chemie der Erde, 71, 349-362.

Fidelis I. \& Siekierski S. (1966) The regularities in stability constants of some rare earth complexes. Journal of Inorganic and Nuclear Chemistry, 28, 185-188.

Guilbert J. \& Park J. (1986) The Geology of Ore Deposits. New York, NY, USA, $985 \mathrm{pp}$.
Hajalilou B. (1999) Tertiary Metallogeny in Western Alborz-Azerbaijan (MianehSiahroud) Focused on Hashtjin Area. PhD thesis, Shahid Beheshti University, 275 pp.

Hannigan R., Dorval E. \& Jones C. (2010) The rare earth element chemistry of estuarine surface sediments in the Chesapeake Bay. Chemical Geology, 272, 20-30.

Hanson G.N. (1989) An approach to trace element modeling using a simple igneous system as an example. Reviews in Mineralogy and Geochemistry, 21, 79-97.

Hedenquist J.W., Arribas A. \& Gonzalez Urien E. (2000) Exploration for epithermal gold deposits. Economic Geology, 13, 245-277.

Hermann A.G., Potts M.J. \& Knake D. (1974) Geochemistry of the rare earth elements in spilites from the oceanic and continental crust. Contributions to Mineralogy and Petrology, 44, 1-16.

Inoue M., Nakamura N. \& Kimura M. (2009) Tetrad effects in REE abundance patterns of chondrules from CM meteorites: implications for aqueous alteration on the CM parent asteroid. Geochimica et Cosmochimica Acta, 73 5224-5239.

Irber W. (1999) The lanthanide tetrad effect and its correlation with $\mathrm{K} / \mathrm{Rb}, \mathrm{Eu} /$ $\mathrm{Eu}^{*}, \mathrm{Sr} / \mathrm{Eu}, \mathrm{Y} / \mathrm{Ho}$, and $\mathrm{Zr} / \mathrm{Hf}$ of evolving peraluminous granite suites. Geochimica et Cosmochimica Acta, 63, 489-508.

Jochum K.P. \& Verma S.P. (1996) Extreme enrichment of Sb, Tl and other trace elements in altered MORB. Chemical Geology, 130, 289-299.

Karadağ M., Kupeli S., Aryk F., Ayhan A., Zedef V. \& Doyen A. (2009) Rare earth element (REE) geochemistry and genetic implications of the Mortaşbauxite deposit (Seydişehir/Konya - southern Turkey). Chemie der Erde-Geochemistry, 69, 143-159.

Kawabe I. (1995) Tetrad effects and fine structures of REE abundance patterns of granitic and rhyolitic rocks: ICP-AES determinations of REE and Y in eight GSJ reference rocks. Geochemical Journal, 29, 213-230.

Kawabe I., Kitahara Y. \& Naito K. (1991) Non chondritic yttrium ratio and lanthanide tetrad effect observed in pre-Cenozoic limestones. Geochemical Journal, 25, 31-44.

Kawabe I., Toriumi T., Ohta A. \& Miura N. (1998) Monoisotopic REE abundances in seawater and the origin of seawater tetrad effect. Geochemical Journal, 32, 213-229.

Kempe U. \& Goldstein S. (1997) Eu anomalies, tetrad effect and HREE enrichment in fluorites from $\mathrm{Sn}$ deposits: evidence for two source mixing and phase separation (abstract). Journal of the Czech Geological Society, 42, 37.

Konrad-Schmolke M., Zack T., O’Brien P.J. \& Bart M. (2011) Fluid migration above a subducted slab - thermodynamic and trace element modeling of fluid-rock interaction in partially overprinted eclogite-facies rocks (Sesia Zone, Western Alps). Earth and Planetary Science Letters, 311, 287-298.

Lackschewitz K.S., Singer A., Botz R., Garbe-Schobnberg D. \& Stoffers P. (2000) Mineralogy and geochemistry of clay minerals near a hydrothermal site in the Escanaba trough, Gorde Ridge, NE Pacific Ocean. Proceedings of the Ocean Drilling Program, Scientific Results, 169, 1-24.

Lee S.G., Asahara Y., Tanaka T., Kim N.H., Kim K.H., Yi K. et al. (2010) La-Ce and Sm-Nd isotopic systematics of early Proterozoic leucogranite with tetrad REE pattern. Chemical Geology, 276, 360-373.

Lee S.G., Masuda A. \& Kim H.S. (1994) An early Proterozoic leuco-granitic gneiss with the REE tetrad phenomenon. Chemical Geology, 114, 59-67.

Leybourne M.I., Peter J.M., Layton-Matthews D., Volsky J. \& Boyle D.R. (2006) Mobility and fractionation of rare earth elements during supergene weathering and gossan formation and chemical modification of massive sulphide gossan. Geochimica et Cosmochimica Acta, 70, 1069-1112.

Li H., Palinkaš L.A., Evans N.J. \& Watanabe K. (2020) Genesis of the Huangsha ping $\mathrm{W}-\mathrm{Mo}-\mathrm{Cu}-\mathrm{Pb}-\mathrm{Zn}$ deposit, south China: role of magmatic water, metasomatized fluids, and basinal brines during intra-continental extension. Geological Journal, 55, 1409-1430.

Liu X., Wang Q., Zhang Q., Zhang Y. \& Li Y. (2016) Genesis of REE minerals in the karstic bauxite in western Guangxi, China, and its constraints on the deposit formation conditions. Ore Geology Reviews, 75, 100-115.

Liu Y.G., Miah M.R.U. \& Schmitt R.A. (1988) Cerium: a chemical tracer for paleooceanic redox conditions. Geochimica et Cosmochimica Acta, 52, 1361-1371.

Long Y., Chi G., Liu J., Jin Z. \& Dai T. (2017) Trace and rare earth elements constraints on the sources of the Yunfeng paleokarstic bauxite deposit in the Xiuwen Qingzhen area, Guizhou, China. Ore Geology Reviews, 91, 404-418. 
Lottermoser B.G. (1992) Rare earth elements and hydrothermal ore formation processes. Ore Geology Reviews, 7, 25-41.

Maiza P.J., Pieroni D. \& Marfil S.A. (2003) Geochemistry of hydrothermal kaolins in the SE area of Los Menucos, Province of Rio Negro, Argentina. Pp. 123-130 in: A Clay Odyssey (E.A. Dominguez, G.R. Mas \& F. Cravero, editors). Elsevier, Amsterdam, The Netherlands.

Masoumi R (2010) Investigation of Mineralogy and Geochemistry of Kaolin Deposit in Kejal Area, Northwest of Hastjin, Ardebil Province. MSc thesis, University of Tabriz (in Persian).

Masuda A. \& Akagi T. (1989) Lanthanide tetrad effect observed in leucogranites from China. Geochemical Journal, 23, 245-253.

Masuda A. \& Ikeuchi Y. (1979) Lanthanide tetrad effect observed in marine environment. Geochemical Journal, 13, 19-22.

Masuda A., Kawakami O., Dohmoto Y. \& Takenaka T. (1987) Lanthanide tetrad effects in nature: two mutually opposite types W and M. Geochemical Journal, 21, 119-124.

McLennan S.M. (1994) Rare earth element geochemistry and the 'tetrad' effect. Geochimica et Cosmochimica Acta, 58, 2025-2033.

Michard A. \& Albarede F. (1986) The REE content of some hydrothermal fluids. Chemical Geology, 55, 51-60.

Mioduski T. (1997) The regular and inverse tetrad effect. Comments on Inorganic Chemistry, 19, 93-119.

Moiroud M., Pucéat E., Donnadieu Y., Bayon G., Guiraud M., Voigt S. et al. (2016) Evolution of neodymium isotopic signature of seawater during the Late Cretaceous: implications for intermediate and deep circulation. Gondwana Research, 36, 503-522.

Monecke T., Dulski P. \& Kempe U. (2007) Origin of convex tetrads in rare earth element patterns of hydrothermally altered siliceous igneous rocks from the Zinnwald Sn-W deposit, Germany. Geochimica et Cosmochimica Acta, 71, 335-353.

Monecke T., Kempe U., Monecke J., Sala M. \& Wolf D. (2002) Tetrad effect in rare earth element distribution patterns: a method of quantification with application to rock and mineral samples from granite-related rare metal deposits. Geochimica et Cosmochimica Acta, 66, 1185-1196.

Mongelli G., Boni M., Buccione R. \& Sinisi R. (2014) Geochemistry of the Apulian karst bauxites (southern Italy): chemical fractionation and parental affinities. Ore Geology Reviews, 63, 9-21.

Mongelli G., Buccione R., Gueguen E., Langone A. \& Sinisi R. (2016) Geochemistry of the Apulian allochthonous karst bauxite, southern Italy: distribution of critical elements and constraints on Late Cretaceous Peri-Tethyan palaeogeography. Ore Geology Reviews, 77, 246-259.

Montoya J.W. \& Hemley J.J. (1975) Activity relations and stabilities in alkali feldspar and Mica alteration reaction. Economic Geology, 70, 577-594.

Murphy K. \& Dymond J. (1984) Rare earth element fluxes and geochemical budget in the eastern equatorial Pacific. Nature, 307, 444-447.

Murray R.W., Ten Brink M.R.B., Gerlach D.C., Russ G.P. \& Jones D.L. (1991) Rare earth, major and trace elements in chert from the Franciscan complex and Monterey Group, California: assessing REE sources to fine grained marine sediments. Geochimica et Cosmochimica Acta, 55, 1875-1895.

Nardi L.V.S., Formoso M.L.L., Jarvis K., Oliveira L., Bastos Neto A.C. \& Fontana E. (2012) REE, Y, Nb, U, and Th contents and tetrad effect in zircon from a magmatic-hydrothermal F-rich system of Sn-rare metalecryolite mineralized granites from the Pitinga Mine, Amazonia, Brazil. Journal of South American Earth Sciences, 33, 34-42.

Nouri T. \& Masoumi R. (2020) Geochemical and industrial properties of the Kejal kaolin deposit, NW Iran. Turkish Journal of Earth Sciences, 29, 325-346.

Nouri T. \& Mohammady Oskouei M. (2016) Processing of Hyperion data set for detection of indicative minerals using a hybrid method in Dost-Bayli, Iran. International Journal of Remote Sensing, 37, 4923-4947.

Nugent L.J. (1970) Theory of the tetrad effect in the lanthanide (III) and actinide (III) series. Journal of Inorganic and Nuclear Chemistry, 32, 3485-3491

Pan Y. (1997) Controls on the fractionation of isovalent trace elements in magmatic and aqueous systems: evidence from $\mathrm{Y} / \mathrm{Ho}, \mathrm{Zr} / \mathrm{Hf}$, and lanthanide tetrad effect - a discussion of the article by M. Bau (1996). Contributions to Mineralogy and Petrology, 128, 405-408.
Pan Y. \& Breaks F.W. (1997) Rare-earth elements in fluorapatite, Separation Lake area, Ontario; evidence for S-type granite-rare-element pegmatite linkage. Canadian Mineralogist, 35, 659-671.

Peppard D.F., Mason G.W. \& Lewey S. (1969) A tetrad effect in the liquidliquid extraction ordering of lanthanides (III). Journal of Inorganic and Nuclear Chemistry, 31, 2271-2272.

Pérez-López R., Joaquín Delgado J., Nieto J. \& Márquez-García B. (2010) Rare earth element geochemistry of sulphide weathering in the São Domingos mine area (Iberian Pyrite Belt): a proxy for fluid-rock interaction and ancient mining pollution. Chemical Geology, 276, 29-40.

Picard S., Lécuyer C., Barrat J.A., Garcia J.P., Dromart G. \& Sheppard S.M.F. (2002) Rare earth element contents of Jurassic fish and reptile teeth and their potential relation to seawater composition (Anglo-Paris Basin, France and England). Chemical Geology, 186, 1-16.

Piepgras D. \& BJacobsen S. (1992) The behavior of rare earth elements in seawater: precise determination of variations in the North Pacific water column. Geochimica et Cosmochimica Acta, 56, 1851-1862.

Pirajno F. (2009) Hydrothermal processes and wall rock alteration. Pp. 73-164 in: Hydrothermal Processes and Mineral Systems. Springer, Dordrecht, The Netherlands.

Plank T. \& Langmuir C.H. (1998) The chemical composition of subducting sediment and its consequences for the crust and mantle. Science Letters Journal, 105, 554-565.

Rollinson H.R. (1993) Using Geochemical Data: Evaluation, Presentation, Interpretation. Longman, Harlow, UK, $352 \mathrm{pp}$.

Siekierski S. (1971) The shape of the lanthanide contraction as reflected in the changes of the unit cell volumes, lanthanide radius and the free energy of complex formation. Journal of Inorganic and Nuclear Chemistry, 33, 377-386.

Stocklin J. (1977) Structural correlation of the Alpine ranges between Iran and Central Asia. Geologique de France, 8, 333-353.

Sverjensky D.A. (1984) Europium redox equilibria in aqueous solution. Earth Planetary Science Letters, 67, 70-78.

Takahashi Y., Tada A. \& Shimizu H. (2004) Distribution of pattern of rare earth ions between water and montmorillonite and its relation to the sorbed species of the ions. Analytical Sciences 20, 1301-1306.

Takahashi Y., Yoshida H., Sato N., Hama K., Yusa Y. \& Shimizu H. (2002) Wand M-type tetrad effects in REE patterns for water-rock systems in the Tono uranium deposit, central Japan. Chemical Geology, 184, 311-335.

Taylor S.R. \& McLennan S.M. (1985) The Continental Crust; Its Composition and Evolution. Blackwell, Oxford, UK, $312 \mathrm{pp}$.

Titley S.R. \& Beane R.E. (1981) Porphyry copper deposits, Part 1. Geologic settings, petrology and tectonogenesis. Economic Geology, 75th Anniversary Volume, 214-235.

Torr L., Proenza J.A., Aiglsperger T., Bover-Arnal T., Villanova-de-Benavent C., Rodrguez-Garca D. et al. (2017) Geological, geochemical and mineralogical characteristics of REE-bearing Las Mercedes bauxite deposit, Dominican Republic. Ore Geology Reviews, 89, 114-131.

Veksler I.V., Dorfman A.M., Kamenetsky M., Dulski P. \& Dingwell D.B. (2005) Partitioning of lanthanides and Y between immiscible silicate and fluoride melts, fluorite and cryolite and the origin of the lanthanide tetrad effect in igneous rocks. Geochimica et Cosmochimica Acta, 69, 2847-2860.

Wood S.A. (1990) The aqueous geochemistry of the rare earth elements and yttrium: theoretical prediction in hydrothermal solutions to $350^{\circ} \mathrm{C}$ at saturation of water vapor pressure. Chemical Geology, 88, 99-125.

Wu F.Y., Sun D.Y., Jahn B.M. \& Wilde S. (2004) A Jurassic garnet-bearing granitic pluton from NE China showing tetrad REE patterns. Journal of Asian Earth Sciences, 23, 731-744.

Yurimoto H., Duke E.F., Papike J.J. \& Shearer C.K. (1990) Are discontinuous chondrite normalized REE patterns in pegmatitic granite systems the results of monazite fractionation? Geochimica et Cosmochimica Acta, 54, 2141-2145.

Zhao J.X. \& Cooper J.A. (1993) Fractionation of monazite in the development of $\mathrm{V}$-shaped REE patterns in leucogranite systems: evidence from a muscovite leucogranite body in central Australia. Lithos, 30, 23-32.

Zhao Z., Bao Z. \& Qiao Y. (2010) A peculiar composite M-and W-type REE tetrad effect: evidence from the Shuiquangou alkaline syenite complex, Hebei Province, China. Chinese Science Bulletin, 55, 2684-2696. 